\title{
Immigrant assimilation and male labor market inequality
}

\author{
Patrick L. Mason
}

Correspondence: pmason@fsu.edu Department of Economics, Florida State University, 266 Bellamy Building, Tallahassee, FL 32306-2180, USA

\begin{abstract}
At the height of the US civil rights movement in the mid-1960s, foreign-born persons were less than $1 \%$ of the African-American population (Kent, Popul Bull, 62:4, 2007). Today, $16 \%$ of America's African diaspora workforce consists of first- or second-generation immigrants and $4 \%$ is Hispanic. Intergenerational improvement is an important source of wage convergence of black immigrants. Unskilled immigrants who arrive in the USA as children and adolescents experience substantial wage assimilation, especially Caribbean-English and African-English immigrants. But both unskilled immigrants arriving as adults and all skilled immigrants fail to catch up to the wage status of either native-born whites or native-born African-Americans. After living in the USA for 9-15 years, first-generation black immigrants will have wage penalties at least as large as native-born African-Americans. The immigration process selects black immigrants who have or who would have achieved middle income or higher status in their country of origin. As such, black immigrants tend to have above average observable characteristics. Nevertheless, black immigrants do not obtain wage assimilation equal to native-born non-Hispanic white male workers.
\end{abstract}

JEL Classification: J15, J31, J61, J62, J7

Keywords: Black immigrants, Assimilation, Discrimination, Immigration, Caribbean, African, Hispanic, Race

\section{Introduction}

At the height of the US civil rights movement in the mid-1960s, foreign-born persons were less than $1 \%$ of the African-American population (Kent, 2007). Today, $16 \%$ of America's African diaspora workforce consists of first- or second-generation immigrants and $4 \%$ is Hispanic. (See Table 1.) The extant literature argues that black immigrant labor market assimilation is governed by positive selection in the immigration process and lateral class mobility of immigrants. ${ }^{1}$ Further, many immigrants arrive in the USA as children and, therefore, are substantively acculturated to the American society prior to full-time entry into the labor market. These factors should support rapid labor market assimilation.

This study empirically describes wage assimilation among black immigrants, with a particular focus on age of arrival effects and their impact on racial wage differentials. The dataset does not have a measure of cognitive ability or quality of education, and this study only imprecisely controls for an immigrant's education in the USA or a source. Nevertheless, the extremely high years of education of some black immigrant

(c) 2016 The Author(s). Open Access This article is distributed under the terms of the Creative Commons Attribution 4.0 International License (http://creativecommons.org/licenses/by/4.0/), which permits unrestricted use, distribution, and reproduction in any medium, provided you give appropriate credit to the original author(s) and the source, provide a link to the Creative Commons license, and indicate if changes were made. 
Table 1 Distribution of African-American ethnic groups, males

\begin{tabular}{llllll}
\hline$N$ & All & Northeast & Northwest & South & West \\
Native-born non-Hispanic black & 77,233 & 13,161 & 13,568 & 42,287 & 8217 \\
Native-born Hispanic black & 0.8307 & 0.5789 & 0.9144 & 0.8875 & 0.8062 \\
Caribbean-English, 2nd gen. & 0.0128 & 0.0325 & 0.0059 & 0.0074 & 0.0210 \\
Caribbean-Spanish, 2nd gen. & 0.0114 & 0.0352 & 0.0039 & 0.0071 & 0.0074 \\
Haiti, 2nd gen. & 0.0045 & 0.0116 & 0.0017 & 0.0029 & 0.0061 \\
African-English, 2nd gen. & 0.0035 & 0.0115 & 0.0005 & 0.0023 & 0.0015 \\
African-French, 2nd gen. & 0.0026 & 0.0029 & 0.0035 & 0.0021 & 0.0033 \\
African-Other language, 2nd gen. & 0.00005 & 0.00003 & 0.0002 & 0.000019 & 0.0000 \\
Other immigrants, 2nd gen. & 0.0009 & 0.0010 & 0.0008 & 0.0007 & 0.0018 \\
Caribbean-English & 0.0096 & 0.0111 & 0.0073 & 0.0062 & 0.0299 \\
Caribbean-Spanish & 0.0356 & 0.1263 & 0.0054 & 0.0203 & 0.0163 \\
Haiti & 0.0126 & 0.0394 & 0.0042 & 0.0073 & 0.0106 \\
African-English & 0.0197 & 0.0492 & 0.0029 & 0.0188 & 0.0032 \\
African-French & 0.0174 & 0.0312 & 0.0150 & 0.0133 & 0.0198 \\
African-Other language & 0.0008 & 0.0015 & 0.0004 & 0.0006 & 0.0007 \\
Other immigrants & 0.0158 & 0.0189 & 0.0197 & 0.0103 & 0.0336 \\
Years in the USA & 0.0234 & 0.0512 & 0.0148 & 0.0142 & 0.0409 \\
& 16.17 & 17.30 & 12.62 & 15.50 & 16.84
\end{tabular}

Distribution of immigrants by selective major geographical areas

\begin{tabular}{|c|c|c|c|c|c|c|c|}
\hline & \multicolumn{3}{|c|}{ Caribbean 2} & \multicolumn{4}{|l|}{ African 2} \\
\hline & English & Spanish & Haiti & English & French & Oth. lang. & Other 2 \\
\hline Connecticut & 0.06 & 0.04 & 0.02 & 0.01 & 0.00 & 0.01 & 0.01 \\
\hline New York & 0.30 & 0.25 & 0.36 & 0.06 & 0.00 & 0.09 & 0.08 \\
\hline New Jersey & 0.05 & 0.05 & 0.06 & 0.02 & 0.00 & 0.01 & 0.02 \\
\hline Maryland & 0.05 & 0.05 & 0.02 & 0.15 & 0.13 & 0.09 & 0.03 \\
\hline District of Columbia & 0.05 & 0.03 & 0.02 & 0.08 & 0.13 & 0.16 & 0.05 \\
\hline Virginia & 0.02 & 0.04 & 0.00 & 0.03 & 0.00 & 0.04 & 0.02 \\
\hline \multirow[t]{3}{*}{ Florida } & 0.14 & 0.10 & 0.26 & 0.03 & 0.00 & 0.02 & 0.04 \\
\hline & \multicolumn{3}{|c|}{ Caribbean } & \multicolumn{4}{|l|}{ African } \\
\hline & English & Spanish & Haiti & English & French & Oth. lang. & Other 2 \\
\hline Connecticut & 0.08 & 0.02 & 0.03 & 0.01 & 0.01 & 0.01 & 0.02 \\
\hline New York & 0.38 & 0.29 & 0.21 & 0.10 & 0.12 & 0.07 & 0.16 \\
\hline New Jersey & 0.07 & 0.06 & 0.09 & 0.06 & 0.01 & 0.02 & 0.05 \\
\hline Maryland & 0.05 & 0.05 & 0.02 & 0.13 & 0.05 & 0.08 & 0.04 \\
\hline District of Columbia & 0.04 & 0.09 & 0.01 & 0.05 & 0.09 & 0.08 & 0.04 \\
\hline Virginia & 0.01 & 0.02 & 0.01 & 0.04 & 0.04 & 0.04 & 0.01 \\
\hline Florida & 0.14 & 0.10 & 0.42 & 0.01 & 0.03 & 0.01 & 0.06 \\
\hline
\end{tabular}

Also, Years in the USA refers only to immigrants and $n=11,203$ (All), 4655 (Northeast), 1195 (Northwest), 4212 (South), and 1141 (West)

groups, the fact that most black immigrants tend to have above average years of education relative to their home country, and the extremely diverse cultural heterogeneity of black immigrants will help shed light on the importance of race in the American labor market. The research provides answers to several questions. One, are the wages of the 
second-generation black immigrants greater than, less than, or equal to the wages of the third- and higher-generation African-Americans? Two, how does immigrant wage assimilation vary by age of arrival and by skill group? Three, do black immigrants obtain wages equal to native-born non-Hispanic white males?

This study finds that intergenerational improvement is an important path of labor market assimilation. Also, unskilled immigrants who arrive in the USA as children and adolescents experience substantial wage assimilation, especially CaribbeanEnglish and African-English immigrants. But both unskilled immigrants arriving as adults and all skilled immigrants fail to catch up to the wage status of either nativeborn whites or native-born African-Americans. In particular, after living in the USA for 9-15 years, most first-generation black male immigrants will have wage penalties higher than the black-white male differential for native-born workers. Additionally, second-generation black male immigrants have substantial wage penalties, penalties that are often similar to the penalties of native-born black males relative to nativeborn white male workers.

Positive selection should lead to rapid the labor market assimilation of black immigrants relative to native-born Americans because the immigration process selects in favor of persons with above average levels of observable and unobservable skills (Butcher, 1994; Dodoo and Takyi, 2002; Model, 2008, 1991; Kalmijn 1996; Pierre, 2004; Hamilton, 2014, 2012). Further, lateral mobility may allow immigrants to achieve American socioeconomic status that is similar to the level of socioeconomic status they held or would have held in their country of origin (Darity 1989; Foner, 1979; Pierre, 2004). With both positive selection and lateral mobility, black immigrants of middle or higher socioeconomic status in their country of origin should achieve the same relative status in the USA, and thus, some black immigrants are more likely to obtain higher socioeconomic status than native-born African-Americans, who are disproportionately poor and of lower socioeconomic status.

The large body of research on immigrant assimilation provides comparative benchmarks for what we should expect for black immigrants. Chiswick (1978) found that the wages of white male immigrants catch up with and overtake the wages of native-born American white males within 10-15 years. Unlike Chiswick, Borjas (1985) does not include Hispanics among whites. When Borjas estimates the non-Hispanic white convergence rate for 1970, the rate is 5-10 years for white immigrants to overtake native-born whites. Also, white immigrants overtake nativeborn whites in 10 years in 1980 (Borjas, 1995). Relative to native-born whites, there is no evidence of earnings deterioration among newly arriving white immigrants in 1970 census (1965-1969 immigrants), 1980 census (1975-1979 immigrants), or 1990 census (1985-1989 immigrants).

Borjas $(1985,1995,2015)$ finds that the white assimilation benchmark does not hold for the 1970s, 1980s, and 1990s Hispanic and Asian immigrant cohorts. The earnings of these immigrants often fail to overtake the earnings of either their own racial group or whites. Hence, rather than race or nativity, Borjas $(2015,1995,1985)$ argues that the non-white immigrants of the late 1970s, 1980s, and 1990s are less skilled than the native-born white workers, nativeborn own-group racial minority workers, and previous cohorts of immigrants.

Black immigrants are often highly skilled with origins in countries where English is the official language. Hence, in the absence of discrimination, their wage 
assimilation should be comparable to white immigrants, rather than the assimilation results of Hispanic and Asian immigrants. Within 10-15 years, black male immigrants should have wages equal to native-born non-Hispanic white males. However, the length of time required for black immigrants to catch up to nativeborn American worker is not a settled empirical issue. For example, Kalmijn (1996) reports that it takes 12, 34, and 21 years, respectively, for first-generation English-speaking, Spanish-speaking, and French-speaking black male Caribbean immigrants to overtake native-born African-American men of the same ancestral origin. However, Borjas (1985: 482) suggests that cross-sectional studies of wage assimilation, such as Kalmijn (1996) and others that dominate the black immigrant assimilation literature, do not carefully distinguish between cohort, duration, and period effects; therefore, these studies may not yield valid inferences on the ability of immigrants to assimilate into the US labor market.

Black immigrant cohort effects for 1965-1969 and 1970-1974 are positive, statistically significant, and substantively large relative to 1975-1979 immigrants (Borjas, 1985). ${ }^{2}$ Borjas takes this as evidence of lower relative skill among late 1970s black immigrants. But this evidence is also consistent with an increase in differential treatment for the 1975-1979 cohort due to greater immigrant discrimination and greater racial discrimination. For the 1950-1959, 1960-1964, and 1965-1969 black male immigrant cohorts, there is no or negative withincohort wage growth, that is, no or negative wage assimilation. On the other hand, there is an across-cohort wage growth, indicating either lower quality or declining market treatment for the 1970-1974 immigrants relative to the 1950s and 1960s immigrants. ${ }^{3}$

The most recent research argues that the first-generation Caribbean-English black male immigrants who arrived in the USA between 1970 and 1989 and during 1995-1999 overtake the income of native-born African-American males within 11-15 years of living in the USA (Hamilton, 2014). The pre-1970, 1990-1994, and 2000-2007 Caribbean-English cohorts will catch up with but not overtake the native-born African-Americans within 11-15 years of arriving in the USA. All of these Caribbean-English cohorts surpass native-born African-American men after more than 20 years in the USA. The 1995-1999 Latin American cohort of black male immigrants catches up to and maintains parity with native-born black males during the 11th and 20th years in the USA; after the 20th year, they have a premium relative to native-born black males. African-English immigrants of the 1985-1989, 1990s, and 2000s cohorts have the most rapid assimilation. Starting with wage penalties that are 25-35 log points below native-born AfricanAmericans (and $10 \mathrm{log}$ points below Caribbean-English immigrants), they obtain parity with native-born black males 11-15 years after being in the USA. (The 1985-1989 cohort requires 16-20 years, but they have the largest penalty on arrival in the USA $(0.355 \log$ points).) No other black male immigrant ethnic group catches up with native-born African-American males.

Nevertheless, after 20 years of duration in the USA, even the most assimilated firstgeneration black immigrants will have very large income penalties relative to nativeborn non-Hispanic white males. For example, among all black male immigrants the 1980-1984 Caribbean-English and 1995-1999 Latin American cohorts have the 
smallest penalties on arrival in the USA. After 20 or more years of American residence, the Caribbean-English will earn $6.5 \%$ more than the native-born black males but $14.7 \%$ less than the native-born non-Hispanic white males, while the Latin American immigrants will earn $1.8 \%$ more than the native-born black males and $19.4 \%$ less than the native-born non-Hispanic white males.

This study is methodologically similar to Hamilton (2014) but differs in important ways. Both studies control for cohort effects, period effects, and duration effects. Hamilton's sample excludes individuals who arrived in the USA before age 18, excludes individuals born in Puerto Rico or the Virgin Islands, and does not distinguish secondgeneration immigrants from third- or higher-generation African-Americans. Hamilton's duration effects do not control for age-on-arrival. Finally, Hamilton controls for national regions, a broad measure of differences in labor markets.

This study controls for the citizenship status of immigrants and years of education obtained in the USA. Native-born African-Americans are separately identified by Hispanic status. Also, this study controls for state of residence rather than region, and there are a complete set of interactions of state fixed effects and time trend. Each of these adjustments affects inferences about black immigrant wage assimilation.

Blacks born in Puerto Rico are a large component of Hispanic black Americans, who have a lower wage penalty than non-Hispanic black Americans and therefore represent an important additional comparative group for assessing the extent of assimilation of black immigrants. Intergenerational mobility may be an important path of immigrant assimilation; hence, it is important to distinguish second-generation immigrants from third- or higher-generation native-born African-Americans. For example, Sakamoto, Woo, and Kim (2010) show that second-generation immigrants have a smaller wage penalty than third- or higher-generation African-Americans, even as second-generation penalties vary by ancestral group.

Separate equations are estimated for persons 16-64 years of age and persons 25-64 years of age. For the latter group, formal schooling is likely to be completed and the individual is more likely to be a full-time market participant. Immigrants who are also citizens are likely to have superior earnings opportunities relative to non-citizens. Immigrants at least partially educated in the USA may have better language skills, speak without an accent, and have greater familiarity with American culture and labor market opportunities. Additionally, as we show below, the effect of duration in the USA on immigrant wage growth varies greatly by age-on-arrival. Specifically, persons who arrive in the USA prior to 26 years of age have dramatically lower wage penalties than older arriving immigrants of the same cohort and ancestral group and are the only black immigrants able to catch up with and overtake native-born non-Hispanic black males workers-but not native-born Hispanic black male workers or same-group second-generation black male immigrants. Finally, inclusion of state-trend interaction terms allows different trends in economic outcomes across state labor markets. This specification controls for factors within state labor markets that may alter immigrant effects if they are not accounted for by the statistical model.

This study is organized as follows. Section 1 presents and discusses the statistical model. Section 2 discusses the data, while the results are presented in Section 3. Section 4 summarizes and briefly discusses the conclusions. 


\section{Statistical model}

Consider the following assimilation equation:

$$
\begin{aligned}
& \ln \mathrm{Y}_{\mathrm{ist}}=\beta_{0}+\gamma_{1} A_{\mathrm{i}}+\gamma_{2} H_{i}+\sum_{n=1}^{7} \alpha_{n} \mathrm{G} 2_{\text {in }}+\sum_{n=1}^{7} \theta_{n} \mathrm{G}_{\text {in }}+\sum_{k=1}^{K} X_{i k} \beta_{k}+\text { Cohort }_{t} \\
& + \text { Age of } \text { arrival }_{i}+\text { Year }_{t}+\text { State }_{s}+(\text { State } * \text { Trend })_{\text {st }}+u_{\text {ist }} \text {, }
\end{aligned}
$$

where $\ln Y_{\text {ist }}$ is alternatively the natural logarithm of weekly wages or the natural logarithm of annual earnings; $A \equiv$ binary variable for third- or higher-generation nonHispanic African-Americans; $H \equiv$ binary variable for third- or higher-generation Hispanic African-Americans; G2 $\equiv$ vector of binary variables for second-generation black immigrants from Caribbean-English, Caribbean-Spanish, Haiti, African-English, African-French, African-Other, and Other source countries, viz., Canada, Mexico, South America, Oceania, Asia, and Europe; $G \equiv$ vector of binary variables for firstgeneration African-American immigrants; X is a vector of labor market covariates, including the citizenship status of immigrants and whether immigrant was educated in the USA; Cohort is a vector of variables that identify alternative periods of arrival in the USA; Age of arrival is a vector of binary variables for ages of arrival in the USA; Year of work fixed effects; State of residence fixed effects; State*Trend is a vector of interactions between a state and a linear trend; and $u$ is an error term.

Cohorts are immigrants' years of arrival, demarcated by major institutional changes (1965 Immigration Act) and alternative recessions: pre-1965, 1965-1974, 1975-1981, 1982-1991, 1992-2001, 2002-2007, and 2008-2013. Year fixed effects cover the work years of 1994-2013. The vectors of binary variables for ages of arrival are as follows: child (no more than 12 years of age), adolescent (13-17 years old), emerging adult (18-25 years of age), young adult (ages 26-34), advanced adult (ages 35-44), middle-age (ages 45-54), and senior (ages 55-64).

The labor market covariates include the following: marital status; health status; and binary variables for small localities (cities with 100,000 or fewer persons) and large cities (metropolitan areas with 5,000,000 or more individuals), experience, and region. Experience is captured by two alternative sets of variables: (1) seven binary variables to capture differing years of potential experience (6-10 years, 11-15 years,..., 31-36 years, 36 or more years of experience), where persons with 5 or fewer years of experience represent the comparative category, and (2) a third-degree polynomial in age. Similarly, the model alternatively uses region and State and State*Trend. All whites are nativeborn non-Hispanic whites. The State*Trend interactions relieve the statistical model of the parallel trends assumption, that is, it allows that workers located in different states may experience different wage trends.

For a given immigrant group, cohort, and arrival age, the differential effect of first-generation immigration status on labor market outcomes is $\delta_{\text {nti }} \equiv \theta_{n}+$ Cohort $_{t}$ + Age of arrival ${ }_{i}$. For a given cohort and immigrant group, the assimilation effect is

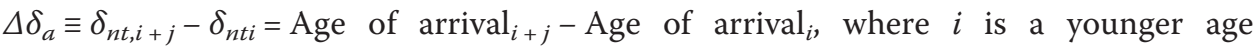
group than $i+j$. For a given age-on-arrival and immigrant group, the cohort effect is $\Delta \delta_{c} \equiv \delta_{n, t+k, i}-\delta_{\text {nti }}=\mathrm{C}_{t+k}-\mathrm{C}_{t}$, where $t$ is an earlier cohort than $t+k$. Assimilation with white workers occurs if there is no residual wage penalty for secondgeneration black immigrants $\left(\alpha_{n}=0\right)$ and first-generation black immigrants are able 
to achieve parity $(\delta=0)$ with non-Hispanic native-born white workers within 10-15 years. It is well established that native-born black Americans have lower wages than observationally identical white Americans; hence, $\gamma_{1}<0$ and $\gamma_{2}<0$ are alternative assimilation benchmarks for second-generation immigrants and first-generation immigrants after 10-15 years in the USA labor market.

\subsection{Positive selection}

If the immigration process is associated with positive skill selection, then we should observe the following: (i) superior observable skill-linked attributes among first-generation immigrants relative to the skill distribution of their country of origin and (ii) assuming a high intergenerational correlation of status, above average education among second-generation black immigrants.

\subsection{Lateral mobility}

Separate regressions are estimated for high school-equivalent (12 or fewer years of education) and college-equivalent (13 or more years of education) workers. ${ }^{4}$ Persons with high status in their country of origin are more likely to be college-equivalent workers, while persons with a low status in their country of origin are more likely to be unskilled workers. If immigrants fully reproduce their class position in the USA, then we should observe immigrant assimilation with white male workers within 10-15 years. Secondgeneration black immigrants within each market segment should have wage parity with native-born white male workers.

\section{Data}

The data are taken from the Current Population Survey Annual Social and Economic Supplement (CPS ASEC) for March 1994-March 2013. Starting in 1994, the CPS ASEC continuously includes information on nativity. The mean weekly wage refers to the year prior to the survey. All individuals are 16-64 years of age during the wage-year. Potential experience $=\max \{$ age of individual - years of education -6 , 0 $\}$. Self-employment patterns differ across cultural groups. Hence, we do not delete the self-employed, despite the fact that their wages may be difficult to determine precisely. The results show that including or excluding self-employed persons does not affect this study's conclusions. All individuals are African-Americans and native-born non-Hispanic whites (hereafter, "white males"). All income data are inflation-adjusted to March \$2011 using the Consumer Price Index-All Urban Consumers.

Puerto Rico and the US Virgin Islands are American territories, and persons born within these territories are American citizens; hence, persons from the US Virgin Islands and Puerto Rico who self-identify as black are considered native-born AfricanAmericans. Native-born Hispanic Americans include all persons who were US citizens at birth, self-identified as Hispanic, and also self-identified as black. Caribbean-English immigrants include persons with origins in English-speaking Caribbean Islands, as well as Guyana and Surinam. Caribbean-Spanish immigrants include Costa Rica; El Salvador; Guatemala; Honduras; Nicaragua; Panama; Cuba; Dominican Republic; South America, not specified; Latin America; and Central America. Haitians are 
Creole- and French-speaking immigrants; hence, they are analyzed separately from the English-speaking and Spanish-speaking Caribbean immigrant groups.

African immigrants include all persons with ancestral origins on the African continent. African observations are separated into African-English, African-French, and African-Other language, according to the official language of the source country. African-French source countries are Algeria, Republic of the Congo, Côte d'Ivoire, Guinea, Morocco, Senegal, and Togo. African-English immigrants include persons with origins in Cameroon, Ghana, Kenya, Liberia, Nigeria, Sierra Leone, South Africa, Uganda, Zambia, and Zimbabwe. African-Other language immigrants are born in Cape Verde; Egypt; Ethiopia; Eritrea; Libya; Somalia; Sudan; Tanzania; Zaire; Africa, not specified, and North Africa.

Finally, the residual category Other immigrants include persons from Mexico, South America, Asia, and Western and Eastern Europe, as well as persons from Canada and Oceania (Australia, Fiji, New Zealand, Tonga, Samoa, and other Oceania, unspecified) and elsewhere (persons whose origins are not specified). As such, Other immigrants of African descent include a large fraction of persons who are English-speaking and who have been socialized into the work norms of an industrialized economy and the social norms of white (or, at least, non-black)-dominated countries.

About $16 \%$ of the 1994-2013 African-American male workforce consists of firstand second-generation immigrants (Table 1). Caribbean and Central American immigrants represent $9 \%$ of the African-American labor force. African immigrants are $4 \%$ of the African-American labor force. An average black immigrant worker has lived in America for 16 years.

African-American immigrants are disproportionately residents of the northeastern states of the USA. First- and second-generation black immigrants represent $39 \%$ of the Northeastern African-American male labor force. The West is the second major region of residence; African-American male immigrants are $19 \%$ of the black labor force. But the bottom panel of Table 1 shows that these regional differences hid considerable concentration by states. More than three of four first-generation Caribbean-English and two of three second-generation Caribbean-English reside in just five states and the District of Columbia: New York-New Jersey-Connecticut, Washington, DC-MarylandVirginia, and Florida. Indeed, Caribbean immigrants are heavily concentrated in New York and Florida, while African and Other immigrants are more evenly spread out across the country. For example, 52, 39, and $63 \%$ of first-generation CaribbeanEnglish, Caribbean-Spanish, and Haitian immigrants, respectively, reside in New York and Florida. Among the second-generation Caribbean-English, Caribbean-Spanish, and Haitian immigrants 45, 35, and $62 \%$, respectively, reside in Florida and New York.

For each ethnic group, 70-80 \% of black immigrants arrived during the 1970s, 1980s, and 1990s (Table 2, top panel). Thirty-six percent of Caribbean-English and $32 \%$ of Haitians arrived during the 1980s, while $29 \%$ of Caribbean-Spanish, $39 \%$ of Africans, and $36 \%$ of Other immigrants arrived during 1992-2001. Nearly six of ten African immigrants are emerging adults or young adults when they arrive in America. Only $14 \%$ are children or adolescents. Thirty-six percent of Caribbean-English are children or adolescents upon arrival in the USA, with $42 \%$ arriving as emerging or young adults. Other immigrants have a high proportion of children and adolescents on arrival (29\%) and a high proportion of emerging and young adults (52\%). Forty-nine and $47 \%$ of 
Table 2 Immigrant cohorts, age-on-arrival, and educational attainment by nativity

\begin{tabular}{|c|c|c|c|c|c|c|c|}
\hline & $\begin{array}{l}\text { Caribbean- } \\
\text { English }\end{array}$ & $\begin{array}{l}\text { Caribbean- } \\
\text { Spanish }\end{array}$ & Haiti & $\begin{array}{l}\text { African- } \\
\text { English }\end{array}$ & $\begin{array}{l}\text { African- } \\
\text { French }\end{array}$ & $\begin{array}{l}\text { African-Oth } \\
\text { Ing }\end{array}$ & $\begin{array}{l}\text { Other } \\
\text { immigrants }\end{array}$ \\
\hline \multicolumn{8}{|l|}{ Cohort } \\
\hline Arrived pre-1965 & 0.0267 & 0.0390 & 0.0091 & 0.0055 & 0.0000 & 0.0013 & 0.0139 \\
\hline Arrived 1965-1974 & 0.1527 & 0.0970 & 0.0892 & 0.0597 & 0.0000 & 0.0277 & 0.0713 \\
\hline Arrived 1975-1981 & 0.1817 & 0.1410 & 0.203 & 0.1142 & 0.0568 & 0.0617 & 0.1298 \\
\hline Arrived 1982-1991 & 0.3646 & 0.2700 & 0.3231 & 0.2072 & 0.1121 & 0.2558 & 0.2972 \\
\hline Arrived 1992-2001 & 0.2171 & 0.2930 & 0.2901 & 0.3716 & 0.4068 & 0.4073 & 0.3639 \\
\hline Arrived 2002-2007 & 0.0486 & 0.1260 & 0.0662 & 0.1950 & 0.2485 & 0.1884 & 0.108 \\
\hline Arrived 2008-2013 & 0.0082 & 0.0350 & 0.0193 & 0.0458 & 0.1759 & 0.0566 & 0.0159 \\
\hline \multicolumn{8}{|c|}{ Age of immigrant on arrival in the USA } \\
\hline Child $(\leq 12)$ & 0.2263 & 0.2030 & 0.1564 & 0.0739 & 0.0151 & 0.0686 & 0.1633 \\
\hline Adolescent (13-17) & 0.1375 & 0.1400 & 0.1004 & 0.0557 & 0.0404 & 0.0767 & 0.1253 \\
\hline Emerging adult (18-25) & 0.2276 & 0.2690 & 0.2397 & 0.3370 & 0.2523 & 0.3102 & 0.3497 \\
\hline Young adult (26-34) & 0.1905 & 0.2020 & 0.2579 & 0.2480 & 0.5052 & 0.2793 & 0.1783 \\
\hline Advanced adult (35-44) & 0.1051 & 0.0600 & 0.1181 & 0.1441 & 0.0812 & 0.1150 & 0.058 \\
\hline Middle-age (45-54) & 0.0229 & 0.0240 & 0.0346 & 0.0376 & 0.0162 & 0.0308 & 0.0279 \\
\hline Senior (55-64) & 0.0048 & 0.0050 & 0.0045 & 0.0042 & 0.0166 & 0.0087 & 0.0028 \\
\hline$N$ & 2759 & 1134 & 1407 & 1531 & 74 & 1512 & 1976 \\
\hline \multicolumn{8}{|l|}{ Educational attainment } \\
\hline & \multicolumn{2}{|l|}{ 1994-2001 } & \multicolumn{2}{|l|}{ 2002-2007 } & \multicolumn{2}{|l|}{ 2008-2013 } & \\
\hline & Dropout & College & Dropout & College & Dropout & College & \\
\hline White & 0.1095 & 0.2729 & 0.0891 & 0.3006 & 0.0656 & 0.3247 & \\
\hline Black, 3rd generation+ & 0.1555 & 0.1327 & 0.1135 & 0.1597 & 0.0888 & 0.1806 & \\
\hline Black, 2nd generation & 0.1388 & 0.2315 & 0.1087 & 0.2373 & 0.0740 & 0.2795 & \\
\hline Black, 1st generation & 0.1880 & 0.2527 & 0.1627 & 0.2771 & 0.1247 & 0.2914 & \\
\hline \multicolumn{8}{|l|}{ Cohort } \\
\hline Arrived pre-1965 & 0.0369 & 0.3520 & 0.088 & 0.4581 & 0.008 & 0.4607 & \\
\hline Arrived 1965-1974 & 0.1093 & 0.3610 & 0.084 & 0.396 & 0.0703 & 0.4193 & \\
\hline Arrived 1975-1981 & 0.2121 & 0.2720 & 0.138 & 0.3186 & 0.0959 & 0.3338 & \\
\hline Arrived 1982-1991 & 0.2159 & 0.2230 & 0.152 & 0.2584 & 0.103 & 0.3372 & \\
\hline Arrived 1992-2001 & 0.2109 & 0.1790 & 0.191 & 0.2411 & 0.1328 & 0.2616 & \\
\hline Arrived 2002-2007 & n.a. & n.a. & 0.24 & 0.2456 & 0.1501 & 0.2321 & \\
\hline Arrived 2008-2013 & n.a. & n.a. & n.a. & n.a. & 0.1872 & 0.2658 & \\
\hline
\end{tabular}

Source: author's calculations, March CPS, 1994-2013. Sample is restricted to men with positive wages

Haitian and Caribbean-Spanish immigrants, respectively, are emerging or young adults, with 10 and $14 \%$ arriving as children or adolescents, respectively.

In 1994-2001, $11 \%$ of native-born whites were dropouts and $27 \%$ were college graduates (Table 2, bottom panel). Among first-generation black immigrants, nearly $19 \%$ were dropouts and $25 \%$ were college graduates. By 2008-2013, 7 \% of native-born whites were dropouts versus $12 \%$ of first-generation black immigrants and $32 \%$ of native-born whites were college graduates versus $29 \%$ of black immigrants. Thus, the first-generation black immigrants had no relative deterioration in this important skill category during 1994-2013. 
For the 1970s and all prior cohorts, the first-generation black immigrants had an equal or higher percentage of college graduates than native-born whites, even as they also had a higher percentage of dropouts. For example, among the 1975-1981 cohort, $27 \%$ of black immigrants had a college degree in 1994-2001, about $32 \%$ had a college degree in 2002-2007, and more than 33 \% had a college degree in 2008-2013. Among native-born whites, $27 \%$ had a college degree in 1994-2001, about $30 \%$ had a college degree in 2002-2007, and more than $32 \%$ had a college degree in 2008-2013. All cohorts of first-generation black immigrants have large increases in college graduates across periods and large decreases in the percentage of dropouts; hence, the 1980s cohort shows educational convergence across time and near parity with white males in 2008-2013. The 1990s cohort also shows intertemporal convergence but does not reach parity with white males.

Some immigrants were educated in the USA and some were educated abroad, prior to arrival in the USA. International differences in education between the USA and the source country may indicate a difference in skill. Accordingly, the empirical model includes binary indicators for whether a first-generation immigrant was educated in the USA. Specifically, it is assumed that if the immigrant arrived in the USA on or before his 17th birthday, he has an American high school education, that is, his 12th year of education was obtained in the USA. If the immigrant arrived in the USA during his 18th or 19th birthday and he has only 13-15 years of education, then those years of education occurred in the USA. If the immigrant arrived in the USA during between his 18th and 21st birthdays and he has 16 years of education, then his bachelor's degree was obtained in the USA. If the immigrant arrived in the USA during between his 18th and 22nd birthdays and he has a graduate degree but his bachelor's degree was obtained outside of the USA, then his graduate degree was awarded by an American university. Certainly, these are not precise indicators of where an immigrant was educated; nevertheless, they do provide an additional (if crude) indicator of skill as measured by years of education.

\subsection{Positive selection}

The observable skills of first- and second-generation immigrants provide evidence of positive selection (Table 3). Second-generation black immigrants have mean levels of education higher than native-born African-Americans, 12.82 for non-Hispanics and 12.36 for Hispanics. Second-generation Caribbean-English (13.6) and African (14.03) immigrants have higher mean levels of education than native-born white Americans. Although they are 7-13 years younger than white males, second-generation Haitians, Caribbean-Spanish, and Other immigrants are within one-half- to three-fourths-year of attaining educational parity with white males.

First-generation Africans are the most skilled group in the sample: $44 \%$ have obtained at least a bachelor's degree-14 percentage points higher than native-born nonHispanic whites. Caribbean-Spanish are the least skilled, averaging 11.2 years of education, $32 \%$ dropouts, and $14 \%$ college graduates.

The major source countries for African immigrants are "Africa, not specified" (23.83\%), Nigeria (18.23\%), Ghana (11.19\%), Ethiopia (9.25\%), Eritrea (6.38\%), and Kenya (6.11\%). Except Ethiopia (Amharic and Oromo) and Eritrea (Arabic), all of the 
Table 3 Labor market outcomes, age, and education, by nativity and by race

\begin{tabular}{|c|c|c|c|c|c|c|c|}
\hline \multicolumn{8}{|c|}{ First-generation black immigrants } \\
\hline & $\begin{array}{l}\text { Caribbean- } \\
\text { English }\end{array}$ & $\begin{array}{l}\text { Caribbean- } \\
\text { Spanish }\end{array}$ & Haiti & $\begin{array}{l}\text { African- } \\
\text { English }\end{array}$ & $\begin{array}{l}\text { African- } \\
\text { French }\end{array}$ & $\begin{array}{l}\text { African- } \\
\text { Other }\end{array}$ & $\begin{array}{l}\text { Other } \\
\text { immig. }\end{array}$ \\
\hline Weekly wage & $\$ 920$ & $\$ 709$ & $\$ 707$ & $\$ 979$ & $\$ 676$ & $\$ 805$ & $\$ 720$ \\
\hline Work hours & 40.9 & 40.4 & 39.8 & 41.9 & 40.0 & 40.5 & 40.3 \\
\hline Age & 40.4 & 37.5 & 40.3 & 39.7 & 37.4 & 37.3 & 35.5 \\
\hline Education & 12.9 & 11.3 & 12.4 & 14.9 & 13.6 & 13.4 & 12.2 \\
\hline Dropout & 0.1265 & 0.3031 & 0.2022 & 0.0193 & 0.1059 & 0.1060 & 0.2293 \\
\hline High school & 0.3752 & 0.3682 & 0.3508 & 0.1861 & 0.2467 & 0.2336 & 0.3268 \\
\hline Some college & 0.2760 & 0.1946 & 0.2713 & 0.2438 & 0.2214 & 0.3302 & 0.2104 \\
\hline College degree & 0.1514 & 0.0980 & 0.1279 & 0.3108 & 0.2804 & 0.2067 & 0.1478 \\
\hline Graduate degree & 0.0709 & 0.0362 & 0.0479 & 0.2399 & 0.1455 & 0.1235 & 0.0857 \\
\hline$N$ & 2757 & 1134 & 1407 & 1528 & 74 & 1511 & 1976 \\
\hline \multicolumn{8}{|l|}{ Native-born } \\
\hline & Non-Hispanic black & Hispanic black & White & & & & \\
\hline Weekly wage & $\$ 786$ & $\$ 749$ & $\$ 1,134$ & & & & \\
\hline Work hours & 39.96 & 39.46 & 41.99 & & & & \\
\hline Age & 37.43 & 33.36 & 38.80 & & & & \\
\hline Education & 12.82 & 12.36 & 13.56 & & & & \\
\hline Dropout & 0.1220 & 0.1764 & 0.0902 & & & & \\
\hline High school & 0.4178 & 0.3945 & 0.3207 & & & & \\
\hline Some college & 0.3043 & 0.3181 & 0.2925 & & & & \\
\hline College degree & 0.1153 & 0.0934 & 0.1993 & & & & \\
\hline Graduate degree & 0.0406 & 0.0176 & 0.0972 & & & & \\
\hline$N$ & 63,185 & 1186 & 626,545 & & & & \\
\hline \multicolumn{8}{|c|}{ Second-generation black Immigrants } \\
\hline Weekly wage & $\$ 793$ & $\$ 827$ & $\$ 533$ & $\$ 686$ & $\$ 643$ & $\$ 966$ & $\$ 747$ \\
\hline Work hours & 37.79 & 39.10 & 34.92 & 34.68 & 38.15 & 39.28 & 38.41 \\
\hline Age & 29.74 & 32.10 & 25.48 & 26.66 & 32.14 & 32.45 & 31.57 \\
\hline Education & 13.62 & 13.10 & 13.06 & 13.96 & 14.79 & 13.43 & 13.29 \\
\hline Dropout & 0.0735 & 0.1229 & 0.1040 & 0.0884 & 0.0000 & 0.1274 & 0.1253 \\
\hline High school & 0.2566 & 0.2880 & 0.2606 & 0.1350 & 0.1799 & 0.3180 & 0.3085 \\
\hline Some college & 0.3952 & 0.3939 & 0.4509 & 0.4167 & 0.2762 & 0.2439 & 0.3176 \\
\hline College degree & 0.1823 & 0.1384 & 0.1550 & 0.2658 & 0.3764 & 0.2241 & 0.1728 \\
\hline Graduate degree & 0.0924 & 0.0568 & 0.0295 & 0.0941 & 0.1675 & 0.0866 & 0.0758 \\
\hline$N$ & 823 & 373 & 238 & 213 & 8 & 82 & 837 \\
\hline
\end{tabular}

Source: author's calculations, March CPS, 1994-2013. Sample is restricted to men with positive wages

named countries are officially English-speaking countries. Each group of these firstgeneration African immigrants would occupy an upper-income or elite-class status in their home country. First-generation Nigerian males in the USA average 15.48 years of education, and $68 \%$ have at least some college education. By comparison, male literacy in Nigeria is $72 \%$ and men average 10 years of education. ${ }^{6}$ Ghanaians, like Nigerians, are West Africans, that is, people with the closest cultural ties and physical resemblance to native-born African-Americans. First-generation Ghanaian 
males in the USA average 14.22 years of education, and $70 \%$ have at least some college education, even as male literacy in Ghana is $78 \%$ and men average 12 years of education.

There are also large differences in the class status of first-generation male East African immigrants and men in their home countries. Specifically, years of education and education beyond high school are 13.9 average years of education and $64 \%, 13.35$ average years of education and $63 \%$, and 14.30 average years of education and $81 \%$ for first-generation immigrants of Ethiopian, Eritrean, and Kenyan origins, respectively. But male literacy and years of education are $49 \%$ and 10 years, $80 \%$ and 5 years, and $91 \%$ and 11 years for Ethiopia, Eritrea, and Kenya, respectively.

Caribbean immigrants tend to have higher levels of education than members of their source and host countries (Thomas-Hope, 2009). Thirty-one percent of Caribbean-English men in the sample have "Caribbean origin, unspecified" as the source country, and $22 \%$ are of Jamaican origin. Per Jamaica's Population and Housing Census 2001, black males in Jamaica have an average of 10.63 years of education versus 12.90 years of education for the first-generation black males in our sample. Hence, first-generation Jamaica males in the USA have the equivalent of an advanced secondary education (in Jamaica) versus a secondary education for black males within Jamaica. If a first-generation immigrant Jamaican black male living in the USA returned to Jamaica, his labor earnings would be 54-126 \% greater than the earnings of the average black male in the Jamaica. ${ }^{7}$ Conversely, a male with 10.63 years of education in the USA is a dropout, and a male with 12.90 years has some college. Regression analysis shows there is a $60 \%$ differential for these two groups of men. English-speaking Caribbean countries have similar education systems and high intra-regional labor mobility. Hence, for both Jamaican in particular and Caribbean-English immigrants in general, first-generation male immigrants in the USA would have upper-income status in their home country.

Between the first and second generations, high school dropouts fall from 29.5 and $18.5 \%$ for Caribbean-Spanish and Haitian men, respectively, to 13.44 and $11.3 \%$. The nation of Haiti has a male literacy rate of $53.4 \%$ (The World Factbook 2013). Eighty-one percent of working-age first-generation Haiti immigrants in the USA have at least 12 years education. Haitian immigrants in the USA would hold a class position among upper-income persons in Haiti.

The primary source countries for black male Caribbean-Spanish immigrants in the USA are Dominican Republic (32 \%), El Salvador (17.12 \%), and Cuba (9.72 \%). Black Dominican males in the USA average 11.56 years of education, and $35 \%$ have education beyond high school. Black male Salvadorians in the USA average 9.8 years of education, and $18.5 \%$ have education beyond high school. Black male Cubans in the USA average 10.74 years of education, and $30 \%$ have education beyond high school. Male literacy and years of education in the Dominican Republic and El Salvador are $90 \%$ and 12 years and $87 \%$ and 12 years, respectively, but male literacy in Cuba is $98 \%$ and men average 15 years of education. Hence, Caribbean-Spanish men in the USA would have a middle-income class status in their home countries, with first-generation Cuban immigrants obtaining less than a middle-income class status in Cuba. 
Other immigrants are a residual group. Thirty percent of first-generation Other immigrants that are black male immigrants are from Mexico. These men average 9.82 years of education, and $14 \%$ have some education beyond high school. Ninety-five percent of men in Mexico are literate, and they average 12 years of education. Hence, the largest group of Other immigrants would have below average social class in their home country.

First-generation Caribbean-English and African immigrants have higher wages (\$949.66 and \$889.96, respectively) than native-born non-Hispanic blacks (\$824.38). Also, second-generation Caribbean-English immigrants (\$861.87) have higher mean weekly wages. Black immigrants are healthier than native-born African-Americans and more likely to be married and to reside in a large city.

\section{Results}

\subsection{A. African-American wage inequality}

Table 4 presents selected coefficients from the initial results of various specifications of the wage assimilation equation for black male immigrants. These results are helpful for summarizing overall outcomes, before proceeding to more complex specifications. The dependent variable for column 3 ("Earnings") is the natural logarithm of annual earnings, while the natural logarithm of hourly earnings is the dependent variable for all other specifications. The sample for column 2 ("Age $\geq 25$ ") is limited to men 25-64 years of age, but the sample includes men 16-64 years of age for all other specifications. Finally, columns 4-6 present results for separate work periods.

There is an inverse relationship between age-on-arrival in the USA and an immigrant's market wage. ${ }^{8}$ Per column 1 , there are positive and decreasing effects for immigrants who arrive as children (15.4\%), adolescents (9.99\%), and emerging adults $(3.13 \%)$ and negative and decreasing effects for immigrants arriving as young adults $(-11.3 \%)$, advanced adults $(-16.5 \%)$, middle-age $(-19.4 \%)$, and seniors $(-12.3 \%$ but insignificant). Measuring from the mid-point of the age range, immigrants arriving as children have been in the USA 9 years longer than immigrants arriving as adolescents and 15 years longer than immigrants arriving as emerging adults. For this 15-year interval, the black immigrant wage differential declines by 12.27 percentage points, that is, $\Delta \delta=0.1540-0.0313$. Similarly, for the 18 years between immigrants arriving as emerging adults and those arriving as advanced adults, $\Delta \delta=19.63$ percentage points.

The first-generation wage penalty varies with cohort and age-on-arrival. For example, first-generation immigrants have a wage penalty of $0.176 \log$ points, that is, $0.1220+$ 0.200 (if they arrived during 1982-1991) - 0.154 (if they arrived in the USA as a child). Restricting the sample to men 25-64 years of age, the first-generation wage penalty is 0.220 . For annual earnings, the first-generation wage penalty is 0.196 . So the labor market penalty for first-generation black male immigrants who arrived as children in the 1980 s is about the same as or lower than the penalty of third- or higher-generation non-Hispanic black males (0.199), but greater than the labor market penalty of thirdor higher-generation Hispanic black males (0.125).

The first-generation labor market penalty is considerably larger for immigrants arriving as adults. For example, focusing on the 1980s cohort, for men who arrived 
Table 4 Male wage inequality: race, nativity, year of arrival, and age at arrival (selected coefficients)

\begin{tabular}{|c|c|c|c|c|c|c|}
\hline & All & Age $\geq 25$ & Earnings & 1994-2001 & $2002-2007$ & $2008-2013$ \\
\hline \multirow[t]{2}{*}{ Non-Hispanic generation 3+ } & $-0.1990^{* * *}$ & $-0.224^{* * *}$ & $-0.243^{* * *}$ & $-0.189^{* * *}$ & $-0.197^{* * *}$ & $-0.209^{* * *}$ \\
\hline & {$[0.0031]$} & {$[0.0033]$} & {$[0.0040]$} & {$[0.0058]$} & {$[0.0051]$} & [0.0053] \\
\hline \multirow[t]{2}{*}{ Hispanic generation 3+ } & $-0.1250^{* * *}$ & $-0.159^{* * *}$ & $-0.133^{* * *}$ & $-0.106^{* *}$ & $-0.121^{* * *}$ & $-0.133^{* * *}$ \\
\hline & {$[0.0210]$} & {$[0.0239]$} & {$[0.0264]$} & {$[0.0438]$} & {$[0.0342]$} & {$[0.0334]$} \\
\hline \multirow[t]{2}{*}{ Generation 2} & $-0.135^{* * *}$ & $-0.121^{* * *}$ & $-0.189^{* * *}$ & $-0.118^{* * *}$ & $-0.141^{* * *}$ & $-0.135^{* * *}$ \\
\hline & {$[0.0145]$} & {$[0.0160]$} & {$[0.0200]$} & {$[0.0305]$} & {$[0.0260]$} & {$[0.0212]$} \\
\hline \multirow[t]{2}{*}{ Generation 1} & -0.1220 & $-0.134^{* * *}$ & $-0.145^{* * *}$ & $-0.0929^{* * *}$ & $-0.113^{* * *}$ & $-0.158^{* * *}$ \\
\hline & [0.0113] & {$[0.0117]$} & {$[0.0143]$} & {$[0.0202]$} & [0.0192] & [0.0196] \\
\hline \multirow[t]{2}{*}{ Arrived pre-1965 } & $-0.175^{* * *}$ & $-0.182^{* * *}$ & $-0.159^{* * *}$ & $-0.238^{* * *}$ & $-0.181^{* * *}$ & -0.0247 \\
\hline & {$[0.0251]$} & {$[0.0262]$} & {$[0.0310]$} & {$[0.0474]$} & {$[0.0416]$} & {$[0.0454]$} \\
\hline \multirow[t]{2}{*}{ Arrived 1965-1974 } & $-0.213^{* * *}$ & $-0.221^{* * *}$ & $-0.224^{* * *}$ & $-0.233^{* * *}$ & $-0.232^{* * *}$ & $-0.169^{* * *}$ \\
\hline & {$[0.0242]$} & {$[0.0251]$} & {$[0.0304]$} & {$[0.0472]$} & {$[0.0403]$} & {$[0.0415]$} \\
\hline \multirow[t]{2}{*}{ Arrived 1975-1981 } & $-0.187^{* * *}$ & $-0.206^{* * *}$ & $-0.182^{* * *}$ & $-0.203^{* * *}$ & $-0.205^{* * *}$ & $-0.162^{* * *}$ \\
\hline & {$[0.0234]$} & {$[0.0240]$} & {$[0.0294]$} & {$[0.0461]$} & {$[0.0380]$} & [0.0403] \\
\hline \multirow[t]{2}{*}{ Arrived 1982-1991 } & $-0.2^{* * *}$ & $-0.24^{* * *}$ & $-0.211^{* * *}$ & $-0.244^{* * *}$ & $-0.221^{* * *}$ & $-0.143^{* * *}$ \\
\hline & {$[0.0218]$} & {$[0.0225]$} & {$[0.0277]$} & {$[0.0442]$} & {$[0.0354]$} & {$[0.0363]$} \\
\hline \multirow[t]{2}{*}{ Arrived 1992-2001 } & $-0.193^{* * *}$ & $-0.275^{* * *}$ & $-0.206^{* * *}$ & $-0.247^{* * *}$ & $-0.177^{* * *}$ & $-0.17^{* * *}$ \\
\hline & {$[0.0224]$} & {$[0.0231]$} & {$[0.0285]$} & {$[0.0481]$} & {$[0.0355]$} & [0.0369] \\
\hline \multirow[t]{2}{*}{ Arrived 2002-2007 } & $-0.188^{* * *}$ & $-0.292^{* * *}$ & $-0.216^{* * *}$ & n.a. & $-0.205^{* * *}$ & $-0.142^{* * *}$ \\
\hline & {$[0.0269]$} & {$[0.0278]$} & {$[0.0345]$} & & {$[0.0503]$} & {$[0.0386]$} \\
\hline \multirow[t]{2}{*}{ Arrived 2008-2013 } & $-0.223^{* * *}$ & $-0.355^{* * *}$ & $-0.39 * * *$ & n.a. & n.a. & $-0.189^{* * *}$ \\
\hline & {$[0.0474]$} & [0.0478] & {$[0.0623]$} & & & {$[0.0551]$} \\
\hline \multirow[t]{2}{*}{ Child $(\leq 12)$} & $0.154^{* * *}$ & $0.154^{* * *}$ & $0.16^{* * *}$ & $0.155^{* * *}$ & $0.172^{* * *}$ & $0.117^{* * *}$ \\
\hline & {$[0.0226]$} & {$[0.0239]$} & {$[0.0287]$} & {$[0.0459]$} & {$[0.0371]$} & {$[0.0372]$} \\
\hline \multirow[t]{2}{*}{ Adolescent (13-17) } & $0.0999^{* * *}$ & $0.0883^{* * *}$ & $0.136^{* * *}$ & $0.107^{* *}$ & 0.077 & $0.13^{* * *}$ \\
\hline & {$[0.0245]$} & {$[0.0256]$} & [0.0309] & {$[0.0498]$} & [0.0398] & {$[0.0400]$} \\
\hline \multirow[t]{2}{*}{ Emerging adult (18-25) } & 0.0313 & $0.0476^{* *}$ & $0.0646^{* *}$ & 0.0453 & 0.00818 & 0.0483 \\
\hline & {$[0.0219]$} & {$[0.0224]$} & {$[0.0276]$} & {$[0.0452]$} & {$[0.0352]$} & {$[0.0359]$} \\
\hline \multirow[t]{2}{*}{ Young adult (26-34) } & $-0.113^{* * *}$ & $-0.0442^{*}$ & $-0.119^{* * *}$ & $-0.0811^{*}$ & $-0.115^{* * *}$ & $-0.135^{* * *}$ \\
\hline & {$[0.0231]$} & {$[0.0234]$} & {$[0.0291]$} & {$[0.0482]$} & {$[0.0371]$} & {$[0.0373]$} \\
\hline \multirow[t]{2}{*}{ Advanced adult (35-44) } & $-0.165^{* * *}$ & $-0.0981^{* * *}$ & $-0.136^{* * *}$ & $-0.142^{* *}$ & $-0.199 * * *$ & $-0.151^{* * *}$ \\
\hline & {$[0.0276]$} & {$[0.0279]$} & {$[0.0343]$} & {$[0.0576]$} & [0.0438] & {$[0.0452]$} \\
\hline \multirow[t]{2}{*}{ Middle-age (45-54) } & $-0.194^{* * *}$ & $-0.129^{* * *}$ & $-0.153^{* * *}$ & $-0.161^{* *}$ & $-0.189^{* * *}$ & $-0.217^{* * *}$ \\
\hline & {$[0.0376]$} & {$[0.0378]$} & {$[0.0477]$} & {$[0.0727]$} & {$[0.0645]$} & {$[0.0611]$} \\
\hline \multirow[t]{2}{*}{ Senior (55-64) } & -0.123 & 0.0112 & -0.118 & -0.233 & -0.0428 & -0.121 \\
\hline & [0.1082] & {$[0.1073]$} & {$[0.1379]$} & [0.3069] & {$[0.1402]$} & {$[0.1607]$} \\
\hline$R$-sq & 0.4248 & 0.2394 & 0.4752 & 0.412 & 0.4399 & 0.4217 \\
\hline N & 703,797 & 590,439 & 703,867 & 226,511 & 249,335 & 227,951 \\
\hline
\end{tabular}

Source: author's calculations. March CPS, 1994-2013. Additional control variables also include educational status (11 years or less, 13-15 years, 16 years, 17 years or more), age, age ${ }^{2}$, age ${ }^{3}$, marital status, limitation on the amount or type of work, region, size of city, year, and state fixed effects. Standard errors are reported in brackets ${ }^{*} p<0.10$; ${ }^{* *} p<0.05$; ${ }^{* * *} p<0.01$

as young adults, the wage penalties are 0.433 (men 16-64 years age), 0.487 (men 25-64 years of age), and 0.469 (annual earnings). For all cohorts and for all ageon-arrival except children, first-generation wage penalties are higher than the wage 
penalty of third- or higher-generation non-Hispanic African-Americans. This is especially true for adult immigrants.

Intergenerational improvement is an important source of wage assimilation. Second-generation immigrants have hourly wage penalties of $13.5 \%$ (All) and $12.1 \%$ (Age $\geq 25$ years of age). For annual earnings, second-generation black male immigrants earn nearly $19 \%$ less than white males. By contrast, third- or highergeneration Hispanic black males earn $12.5 \%$ (All), $15.9 \%$ (Age $\geq 25$ years of age), and $18.9 \%$ (Earnings) less than white males. Hence, intergenerational mobility appears to assimilate black immigrants toward mean native-born African-American earnings more so than mean white male earnings.

There is an improvement in the cohort effect of new immigrants. Black immigrants arriving in 1992-2001 had a cohort penalty of $24.7 \%$ during 1994-2001, while immigrants arriving in 2002-2007 and 2008-2013 had cohort penalties of 20.5 and $18.9 \%$ during 2002-2007 and 2008-2013, respectively. This pattern indicates that recent black immigrants are at least as skilled as or face no more discrimination than earlier cohorts of black immigrants. For the 1990s arrivals, their cohort penalty declines by 8 percentage points during the 13-year interval from 1994-2001 to 2008-2013, moving from nearly 25 to $17 \%$. By comparison, the 1980 s cohort saw a 10 percentage point decline in their wage penalty during this same time interval, and the 2000s cohort experienced a 7 percentage point decline in its wage penalty for the 6 years between 2002-2007 and 2008-2013 periods.

For a direct comparison with Chiswick's (1978) specification, we estimated five specifications of the wage equation without age-on-arrival effects, using instead linear and quadratic interactions of years in the USA since immigration with firstgeneration immigrant. The initial specification includes all observations, while the second omits men who arrived in the USA prior to adulthood. The third specification is limited to men who were not self-employed, and the fourth equation includes only men at least 25 years of age. The final specification is the most restrictive: all men who arrived in the USA as adults, none are self-employed, and each man is at least 25 years of age. The results are robust to changes in sample filters. For a firstgeneration black immigrant who arrives during 1982-1991, there is an initial wage penalty of $38.6 \%$. The duration effects indicate that after 15 years, the immigrant wage penalty will be about $32.5 \%$, greater than the wage penalty for native-born black males and far below the earnings of white males. For the 1975-1981 and 1992-2001 cohorts, the entry differentials are 35.1 and $40.3 \%$, respectively, declining to 29 and $34.2 \%$ after 15 years. So $\Delta \delta_{a} \cong 6.1$ percentage points after 15 years for the Chiswick specification.

\subsection{B. Black immigrant diversity}

The results for all immigrants conceal differences by ethnicity and skill group. Accordingly, Table 5 includes seven specifications of the wage assimilation equation. The hourly wage rate is the dependent variable in each specification, and each includes men 16-64 years of age. Tables 10 and 11 of the Appendix present results when the dependent variable is annual earnings and the sample is restricted to men 25-64 years of age, respectively. The columns labeled "Exper" and "Age" are identical 
Table 5 Male hourly wage inequality: race, immigrant ethnicity, and age at arrival (selected coefficients)

\begin{tabular}{|c|c|c|c|c|c|c|c|}
\hline & Exper & Age & Afr. lang & Educ & State & All & Full \\
\hline \multirow{2}{*}{$\begin{array}{l}\text { Non-Hispanic } \\
\text { generation } 3+\end{array}$} & $-0.17^{* * *}$ & $-0.183^{* * *}$ & $-0.183^{* * *}$ & $-0.183^{* * *}$ & $-0.199 * * *$ & $-0.199^{* * *}$ & $-0.199^{* * *}$ \\
\hline & {$[0.0031]$} & {$[0.0031]$} & {$[0.0031]$} & {$[0.0031]$} & {$[0.0031]$} & {$[0.0031]$} & [0.0031] \\
\hline \multirow[t]{2}{*}{ Hispanic generation 3+ } & $-0.117^{* * *}$ & $-0.12^{* * *}$ & $-0.12^{* * *}$ & $-0.12^{* * *}$ & $-0.126^{* * *}$ & $-0.126^{* * *}$ & $-0.127^{* * *}$ \\
\hline & {$[0.0212]$} & {$[0.0210]$} & {$[0.0210]$} & {$[0.0210]$} & {$[0.0210]$} & {$[0.0210]$} & {$[0.0211]$} \\
\hline \multirow[t]{2}{*}{ Caribbean-English 2} & $-0.117^{* * *}$ & $-0.134^{* * *}$ & $-0.134^{* * *}$ & $-0.134^{* * *}$ & $-0.14^{* * *}$ & $-0.141^{* * *}$ & $-0.139 * * *$ \\
\hline & {$[0.0257]$} & {$[0.0248]$} & {$[0.0248]$} & {$[0.0248]$} & {$[0.0248]$} & {$[0.0248]$} & {$[0.0248]$} \\
\hline \multirow[t]{2}{*}{ Caribbean-Spanish 2} & $-0.11^{* * *}$ & $-0.0989^{* * *}$ & $-0.0989^{* * *}$ & $-0.0991^{* * *}$ & $-0.107^{* * *}$ & $-0.107^{* * *}$ & $-0.109^{* * *}$ \\
\hline & {$[0.0384]$} & {$[0.0376]$} & {$[0.0376]$} & {$[0.0376]$} & {$[0.0374]$} & {$[0.0374]$} & {$[0.0375]$} \\
\hline \multirow[t]{2}{*}{ Haiti 2} & $-0.178^{* * *}$ & $-0.177^{* * *}$ & $-0.177^{* * *}$ & $-0.177^{* * *}$ & $-0.169^{* * *}$ & $-0.17^{* * *}$ & $-0.168^{* * *}$ \\
\hline & [0.0543] & {$[0.0542]$} & {$[0.0542]$} & {$[0.0542]$} & {$[0.0540]$} & {$[0.0540]$} & {$[0.0540]$} \\
\hline \multirow[t]{2}{*}{ African 2} & $-0.0912^{* *}$ & $-0.11^{* * *}$ & & $-0.11^{* * *}$ & $-0.134^{* * *}$ & & \\
\hline & {$[0.0438]$} & {$[0.0420]$} & & {$[0.0420]$} & {$[0.0422]$} & & \\
\hline \multirow[t]{2}{*}{ African-English 2} & & & $-0.16^{* * *}$ & & & $-0.181^{* * *}$ & $-0.185^{* * *}$ \\
\hline & & & [0.0519] & & & [0.0520] & {$[0.0520]$} \\
\hline \multirow[t]{2}{*}{ African-Non-English 2} & & & 0.00745 & & & -0.0278 & -0.0263 \\
\hline & & & {$[0.0684]$} & & & {$[0.0695]$} & {$[0.0690]$} \\
\hline \multirow[t]{2}{*}{ Other immigrants 2} & $-0.117^{* * *}$ & $-0.12^{* * *}$ & $-0.12^{* * *}$ & $-0.12^{* * *}$ & $-0.132^{* * *}$ & $-0.132^{* * *}$ & $-0.132^{* * *}$ \\
\hline & {$[0.0257]$} & {$[0.0249]$} & [0.0249] & {$[0.0249]$} & {$[0.0249]$} & {$[0.0249]$} & {$[0.0249]$} \\
\hline \multirow[t]{2}{*}{ Citizen } & 0.00159 & $0.0294^{* *}$ & $0.029 * *$ & $0.0296^{* *}$ & $0.0295^{* *}$ & $0.0294^{* *}$ & $0.0303^{* *}$ \\
\hline & {$[0.0150]$} & {$[0.0147]$} & {$[0.0147]$} & {$[0.0148]$} & {$[0.0147]$} & {$[0.0148]$} & {$[0.0148]$} \\
\hline \multirow[t]{2}{*}{ Caribbean-English } & $-0.0538^{* * *}$ & $-0.0502^{* * *}$ & $-0.05^{* * *}$ & $-0.0555^{* * *}$ & $-0.0516^{* * *}$ & $-0.0576^{* * *}$ & $-0.0589^{* * *}$ \\
\hline & {$[0.0178]$} & {$[0.0176]$} & {$[0.0176]$} & [0.0198] & {$[0.0176]$} & [0.0199] & [0.0199] \\
\hline \multirow[t]{2}{*}{ Caribbean-Spanish } & $-0.118^{* * *}$ & $-0.138^{* * *}$ & $-0.138^{* * *}$ & $-0.143^{* * *}$ & $-0.148^{* * *}$ & $-0.153^{* * *}$ & $-0.154^{* * *}$ \\
\hline & {$[0.0243]$} & {$[0.0236]$} & [0.0236] & {$[0.0246]$} & {$[0.0236]$} & {$[0.0247]$} & {$[0.0246]$} \\
\hline \multirow[t]{2}{*}{ Haiti } & $-0.223^{* * *}$ & $-0.227^{* * *}$ & $-0.227^{* * *}$ & $-0.232^{* * *}$ & $-0.214^{* * *}$ & $-0.219^{* * *}$ & $-0.22^{* * *}$ \\
\hline & {$[0.0227]$} & {$[0.0223]$} & {$[0.0223]$} & {$[0.0237]$} & [0.0222] & {$[0.0236]$} & {$[0.0236]$} \\
\hline \multirow[t]{2}{*}{ African } & $-0.187^{* * *}$ & $-0.174^{* * *}$ & & $-0.177^{* * *}$ & $-0.191^{* * *}$ & & \\
\hline & [0.0184] & {$[0.0180]$} & & [0.0193] & {$[0.0181]$} & & \\
\hline \multirow[t]{2}{*}{ African-English } & & & $-0.147^{* * *}$ & & & $-0.166^{* * *}$ & $-0.168^{* * *}$ \\
\hline & & & [0.0219] & & & {$[0.0230]$} & {$[0.0230]$} \\
\hline \multirow[t]{2}{*}{ African-French } & & & $-0.267^{* * *}$ & & & $-0.28^{* * *}$ & $-0.28^{* * *}$ \\
\hline & & & {$[0.0735]$} & & & {$[0.0734]$} & {$[0.0733]$} \\
\hline \multirow[t]{2}{*}{ African-Other lang. } & & & $-0.197^{* * *}$ & & & $-0.219^{* * *}$ & $-0.22^{* * *}$ \\
\hline & & & {$[0.0227]$} & & & {$[0.0238]$} & {$[0.0238]$} \\
\hline \multirow[t]{2}{*}{ Other immigrants } & $-0.115^{* * *}$ & $-0.136^{* * *}$ & $-0.136^{* * *}$ & $-0.14^{* * *}$ & $-0.14^{* * *}$ & $-0.146^{* * *}$ & $-0.146^{* * *}$ \\
\hline & {$[0.0201]$} & {$[0.0196]$} & [0.0196] & [0.0209] & {$[0.0196]$} & {$[0.0209]$} & {$[0.0209]$} \\
\hline \multirow[t]{2}{*}{ Arrived pre-1965 } & $-0.103^{* * *}$ & $-0.176^{* * *}$ & $-0.176^{* * *}$ & $-0.172^{* * *}$ & $-0.175^{* * *}$ & $-0.17^{* * *}$ & $-0.172^{* * *}$ \\
\hline & [0.0253] & {$[0.0251]$} & {$[0.0251]$} & {$[0.0260]$} & {$[0.0251]$} & {$[0.0260]$} & {$[0.0259]$} \\
\hline \multirow[t]{2}{*}{ Arrived 1965-1974 } & $-0.122^{* * *}$ & $-0.214^{* * *}$ & $-0.214^{* * *}$ & $-0.21^{* * *}$ & $-0.218^{* * *}$ & $-0.214^{* * *}$ & $-0.215^{* * *}$ \\
\hline & {$[0.0244]$} & {$[0.0242]$} & {$[0.0242]$} & {$[0.0248]$} & {$[0.0242]$} & {$[0.0247]$} & {$[0.0247]$} \\
\hline \multirow[t]{2}{*}{ Arrived 1975-1981 } & $-0.111^{* * *}$ & $-0.187^{* * *}$ & $-0.188^{* * *}$ & $-0.184^{* * *}$ & $-0.189^{* * *}$ & $-0.186^{* * *}$ & $-0.186^{* * *}$ \\
\hline & {$[0.0236]$} & {$[0.0234]$} & [0.0234] & {$[0.0239]$} & {$[0.0234]$} & {$[0.0239]$} & [0.0239] \\
\hline
\end{tabular}


Table 5 Male hourly wage inequality: race, immigrant ethnicity, and age at arrival (selected coefficients) (Continued)

\begin{tabular}{|c|c|c|c|c|c|c|c|}
\hline \multirow[t]{2}{*}{ Arrived 1982-1991 } & $-0.142^{* * *}$ & $-0.196^{* * *}$ & $-0.196^{* * *}$ & $-0.193^{* * *}$ & $-0.2^{* * *}$ & $-0.197^{* * *}$ & $-0.197^{* * *}$ \\
\hline & [0.0220] & {$[0.0218]$} & {$[0.0218]$} & {$[0.0224]$} & {$[0.0218]$} & {$[0.0224]$} & {$[0.0224]$} \\
\hline \multirow[t]{2}{*}{ Arrived 1992-2001 } & $-0.138^{* * *}$ & $-0.176^{* * *}$ & $-0.175^{* * *}$ & $-0.173^{* * *}$ & $-0.177^{* * *}$ & $-0.174^{* * *}$ & $-0.173^{* * *}$ \\
\hline & {$[0.0228]$} & {$[0.0225]$} & {$[0.0225]$} & {$[0.0229]$} & {$[0.0225]$} & {$[0.0230]$} & {$[0.0230]$} \\
\hline \multirow[t]{2}{*}{ Arrived 2002-2007 } & $-0.125^{* * *}$ & $-0.153^{* * *}$ & $-0.153^{* * *}$ & $-0.151^{* * *}$ & $-0.159^{* * *}$ & $-0.155^{* * *}$ & $-0.155^{* * *}$ \\
\hline & {$[0.0277]$} & {$[0.0274]$} & {$[0.0274]$} & {$[0.0278]$} & {$[0.0273]$} & {$[0.0278]$} & {$[0.0278]$} \\
\hline \multirow[t]{2}{*}{ Arrived 2008-2013 } & $-0.134^{* * *}$ & $-0.179^{* * *}$ & $-0.175^{* * *}$ & $-0.176^{* * *}$ & $-0.186^{* * *}$ & $-0.179^{* * *}$ & $-0.181^{* * *}$ \\
\hline & [0.0490] & {$[0.0478]$} & {$[0.0479]$} & {$[0.0482]$} & {$[0.0477]$} & {$[0.0480]$} & {$[0.0479]$} \\
\hline \multirow[t]{2}{*}{ Child $(\leq 12)$} & $0.0916^{* * *}$ & $0.156^{* * *}$ & $0.156^{* * *}$ & $0.151^{* * *}$ & $0.152^{* * *}$ & $0.147^{* * *}$ & $0.148^{* * *}$ \\
\hline & {$[0.0228]$} & {$[0.0226]$} & {$[0.0226]$} & {$[0.0237]$} & {$[0.0226]$} & {$[0.0237]$} & {$[0.0237]$} \\
\hline \multirow[t]{2}{*}{ Adolescent (13-17) } & $0.0774^{* * *}$ & $0.0982^{* * *}$ & $0.0988^{* * *}$ & $0.0924^{* * *}$ & $0.0947^{* * *}$ & $0.0884^{* * *}$ & $0.0885^{* * *}$ \\
\hline & {$[0.0247]$} & {$[0.0245]$} & {$[0.0245]$} & {$[0.0264]$} & {$[0.0245]$} & {$[0.0264]$} & {$[0.0264]$} \\
\hline \multirow[t]{2}{*}{ Emerging adult (18-25) } & 0.0212 & 0.0359 & 0.0357 & 0.0357 & 0.0331 & 0.0327 & 0.0324 \\
\hline & {$[0.0221]$} & {$[0.0219]$} & {$[0.0219]$} & {$[0.0220]$} & {$[0.0219]$} & {$[0.0220]$} & {$[0.0220]$} \\
\hline \multirow[t]{2}{*}{ Young adult (26-34) } & $-0.0949 * * *$ & $-0.105^{* * *}$ & $-0.105^{* * *}$ & $-0.105^{* * *}$ & $-0.109^{* * *}$ & $-0.108^{* * *}$ & $-0.107^{* * *}$ \\
\hline & {$[0.0233]$} & {$[0.0230]$} & [0.0230] & {$[0.0231]$} & {$[0.0230]$} & {$[0.0231]$} & {$[0.0230]$} \\
\hline \multirow[t]{2}{*}{ Advanced adult (35-44) } & $-0.149^{* * *}$ & $-0.166^{* * *}$ & $-0.168^{* * *}$ & $-0.166^{* * *}$ & $-0.168^{* * *}$ & $-0.169^{* * *}$ & $-0.168^{* * *}$ \\
\hline & {$[0.0279]$} & {$[0.0276]$} & {$[0.0276]$} & {$[0.0276]$} & {$[0.0275]$} & {$[0.0276]$} & {$[0.0276]$} \\
\hline \multirow[t]{2}{*}{ Middle-age (45-54) } & $-0.199^{* * *}$ & $-0.193^{* * *}$ & $-0.194^{* * *}$ & $-0.192^{* * *}$ & $-0.196^{* * *}$ & $-0.196^{* * *}$ & $-0.196^{* * *}$ \\
\hline & [0.0388] & {$[0.0375]$} & {$[0.0375]$} & {$[0.0375]$} & {$[0.0374]$} & {$[0.0374]$} & {$[0.0374]$} \\
\hline \multirow[t]{2}{*}{ Senior (55-64) } & -0.113 & -0.138 & -0.134 & -0.137 & -0.131 & -0.126 & -0.124 \\
\hline & [0.1103] & {$[0.1074]$} & {$[0.1074]$} & {$[0.1074]$} & [0.1080] & {$[0.1081]$} & [0.1079] \\
\hline$R$-sq & 0.4061 & 0.4216 & 0.4216 & 0.4216 & 0.4249 & 0.4249 & 0.4256 \\
\hline N & 703,797 & 703,797 & 703,797 & 703,797 & 703,797 & 703,797 & 703,797 \\
\hline
\end{tabular}

Source: author's calculations. March CPS, 1994-2013. Additional control variables also include citizenship status, educational status (11 years or less, 13-15 years, 16 years, 17 years or more), experience (binary variables for each 5-year interval from 6 to 35 years, plus a binary variable for more than 36 years of experience), age, age ${ }^{2}$, age ${ }^{3}$, marital status, region, size of city, health status, year fixed effects, state fixed effects, and state*trend interaction effects. Robust standard errors are reported in parentheses

${ }^{*} p<0.10$; ${ }^{* *} p<0.05 ;{ }^{* * *} p<0.01$

regressions, except the former uses a vector of potential experience covariates to control for work experience, while the latter includes age, age $^{2}$, and age $\mathrm{e}^{3}$ as controls for work experience. Given the extremely limited number of observations on secondgeneration African-French, they are combined with second-generation African-Other language to form African-Non-English. The "Afr. lang." column decomposes the second-generation African immigrants into two language groups, African-English and African-Non-English, while the first-generation African immigrants include AfricanEnglish, African-French, and African-Other language. The "Educ" specification includes a vector of binary indicators for whether an immigrant obtained a high school diploma, some college, a college degree, or a graduate degree in the USA. State fixed effects are added to the specification in column 5. The "All" specification simultaneously incorporates all of the changes associated with columns 2-5. Finally, the "Full" specification adds a vector of state"trend interaction terms to the All equation. This is the preferred specification. 
Regardless of ethnicity, the results show that intergenerational wage assimilation of black immigrants tends to bring their wages closer to native-born black male workers rather than the higher wage level of white male workers. Mostly, the wage penalties of second-generation black immigrants have a range of 10.9-18.5\%. There is a similar range of penalties for native-born Hispanic and non-Hispanic African-Americans, 12.7 and $19.9 \%$, respectively. The point estimate for secondgeneration African-Non-English is an exception; for this small group (90 observations), the wage penalty is small (2.63 \%) and is not measured precisely. However, this exception does not hold for annual earnings inequality. Table 10 of the Appendix shows that the earnings penalties for second-generation black male immigrants range from 14.6 to $29.6 \%$. Again, this overlaps with the range of earnings penalties for native-born Hispanic and non-Hispanic African-Americans, 13.5 and $24.2 \%$, respectively.

First-generation wage penalties are the sum of the immigrant, age-on-arrival, and cohort coefficients. Focusing on the 1982-1991 cohort, Table 6 presents the immigrant wage penalties by age of arrival. The "Full" column of Table 6 is the wage penalties derived from the Full specification of Table 5. The other columns provide wage penalties from the same specification but for different work periods. For all ages of arrival and for each work period, Caribbean-English immigrants have the smallest wage penalties of any first-generation black immigrant ethnic group. For example, Caribbean-English immigrants arriving in the USA as children and adolescents during 1982-1991 have an earnings penalties of 10.79 and $16.74 \%$, respectively, while Other immigrants and African-English immigrants arriving as children have wage penalties of 19.5 and $25.5 \%$ and 21.7 and $27.7 \%$, respectively.

Moreover, except black male Caribbean-English immigrants arriving in the USA as children, the first-generation immigrants tend to have higher wage penalties than the third- and higher-generation African-American Americans-regardless of age of arrival or work period. For example, Caribbean-Spanish immigrants arriving as children have wage penalties of $25.10 \%$ (1994-2001), $23.7 \%$ (2002-2007), and $15.9 \%$ (2008-2013), higher than the penalties of native-born Hispanic and nonHispanic African-Americans, 12.7 and $19.9 \%$, respectively.

Haitian, African-French, and African-Other language immigrants have the highest wage penalties. Creole- and French-speaking Haitian immigrants who arrive in the USA as children have a wage penalty of nearly $27 \%$, more than double the wage penalty of Caribbean-English immigrants who arrived as members of the same cohort and age group. Similarly, African-French immigrants who arrived as children have a wage penalty of $33 \%$. But this is a small group (74 observations). For the 1982-1991 cohort, African-Other language immigrants arriving as children have a wage penalty of 26.70 .

African-English immigrants have surprisingly large wage penalties. For example, African immigrants arriving as adolescents with the 1982-1991 have a wage penalty of $35.5 \%$ in 1994-2001, $29.7 \%$ in 2002-2007, and $22.3 \%$ during 2008-2013. Hence, the wage penalty for this English language immigrant group is persistently greater than the wage penalty for third- and higher-generation non-Hispanic African-Americans. Other immigrants arriving as children, adolescents, and emerging adults have wage penalties that equal or exceed third- or higher-generation non- 
Table 6 Estimates of wage penalty $(\delta)$ for the 1982-1991 cohort, by age-on-arrival, ethnicity, and period

\begin{tabular}{|c|c|c|c|c|c|}
\hline & Full & 1994-2001 & 2002-2007 & 2008-2013 & \\
\hline Child $(\leq 12)$ & -0.1079 & -0.1121 & -0.1147 & -0.1360 & Caribbean-English \\
\hline Adolescent (13-17) & -0.1674 & -0.1777 & -0.2045 & -0.1280 & \\
\hline Emerging adult (18-25) & -0.2235 & -0.2043 & -0.2788 & -0.1966 & \\
\hline Young adult (26-34) & -0.3629 & -0.3160 & -0.4117 & -0.3710 & \\
\hline Advanced adult (35-44) & -0.4239 & -0.3911 & -0.5007 & -0.3940 & \\
\hline Middle-age (45-54) & -0.4519 & -0.4031 & -0.4937 & -0.4580 & \\
\hline Senior (55-64) & -0.3799 & -0.4681 & -0.3543 & -0.3560 & \\
\hline Child $(\leq 12)$ & -0.2030 & -0.2510 & -0.2370 & -0.1590 & Caribbean-Spanish \\
\hline Adolescent (13-17) & -0.2625 & -0.3166 & -0.3268 & -0.1510 & \\
\hline Emerging adult (18-25) & -0.3186 & -0.3432 & -0.4011 & -0.2196 & \\
\hline Young adult (26-34) & -0.4580 & -0.4549 & -0.5340 & -0.3940 & \\
\hline Advanced adult (35-44) & -0.5190 & -0.5300 & -0.6230 & -0.4170 & \\
\hline Middle-age (45-54) & -0.5470 & -0.5420 & -0.6160 & -0.4810 & \\
\hline Senior (55-64) & -0.4750 & -0.6070 & -0.4766 & -0.3790 & \\
\hline Child $(\leq 12)$ & -0.2690 & -0.2880 & -0.2630 & -0.2980 & Haiti \\
\hline Adolescent (13-17) & -0.3285 & -0.3536 & -0.3528 & -0.2900 & \\
\hline Emerging adult (18-25) & -0.3846 & -0.3802 & -0.4271 & -0.3586 & \\
\hline Young adult (26-34) & -0.5240 & -0.4919 & -0.5600 & -0.5330 & \\
\hline Advanced adult (35-44) & -0.5850 & -0.5670 & -0.6490 & -0.5560 & \\
\hline Middle-age (45-54) & -0.6130 & -0.5790 & -0.6420 & -0.6200 & \\
\hline Senior (55-64) & -0.5410 & -0.6440 & -0.5026 & -0.5180 & \\
\hline Child $(\leq 12)$ & -0.2170 & -0.2890 & -0.2070 & -0.2310 & African-English \\
\hline Adolescent (13-17) & -0.2765 & -0.3546 & -0.2968 & -0.2230 & \\
\hline Emerging adult (18-25) & -0.3326 & -0.3812 & -0.3711 & -0.2916 & \\
\hline Young adult (26-34) & -0.4720 & -0.4929 & -0.5040 & -0.4660 & \\
\hline Advanced adult (35-44) & -0.5330 & -0.5680 & -0.5930 & -0.4890 & \\
\hline Middle-age (45-54) & -0.5610 & -0.5800 & -0.5860 & -0.5530 & \\
\hline Senior (55-64) & -0.4890 & -0.6450 & -0.4466 & -0.4510 & \\
\hline Child $(\leq 12)$ & -0.3290 & -0.7790 & 0.0076 & -0.3860 & African-French \\
\hline Adolescent (13-17) & -0.3885 & -0.8446 & -0.0822 & -0.3780 & \\
\hline Emerging adult (18-25) & -0.4446 & -0.8712 & -0.1565 & -0.4466 & \\
\hline Young adult (26-34) & -0.5840 & -0.9829 & -0.2894 & -0.6210 & \\
\hline Advanced adult (35-44) & -0.6450 & -1.0580 & -0.3784 & -0.6440 & \\
\hline Middle-age (45-54) & -0.6730 & -1.0700 & -0.3714 & -0.7080 & \\
\hline Senior (55-64) & -0.6010 & -1.1350 & -0.2320 & -0.6060 & \\
\hline Child $(\leq 12)$ & -0.2690 & -0.3630 & -0.2070 & -0.3060 & African-Other language \\
\hline Adolescent (13-17) & -0.3285 & -0.4286 & -0.2968 & -0.2980 & \\
\hline Emerging adult (18-25) & -0.3846 & -0.4552 & -0.3711 & -0.3666 & \\
\hline Young adult (26-34) & -0.5240 & -0.5669 & -0.5040 & -0.5410 & \\
\hline Advanced adult (35-44) & -0.5850 & -0.6420 & -0.5930 & -0.5640 & \\
\hline Middle-age (45-54) & -0.6130 & -0.6540 & -0.5860 & -0.6280 & \\
\hline Senior (55-64) & -0.5410 & -0.7190 & -0.4466 & -0.5260 & \\
\hline
\end{tabular}


Table 6 Estimates of wage penalty $(\delta)$ for the 1982-1991 cohort, by age-on-arrival, ethnicity, and period (Continued)

\begin{tabular}{llllll}
\hline Child ( $\leq 12)$ & -0.1950 & -0.1899 & -0.2060 & -0.2100 & Other immigrants \\
Adolescent (13-17) & -0.2545 & -0.2555 & -0.2958 & -0.2020 & \\
Emerging adult (18-25) & -0.3106 & -0.2821 & -0.3701 & -0.2706 & \\
Young adult (26-34) & -0.4500 & -0.3938 & -0.5030 & -0.4450 & \\
Advanced adult (35-44) & -0.5110 & -0.4689 & -0.5920 & -0.4680 & \\
Middle-age (45-54) & -0.5390 & -0.4809 & -0.5850 & -0.5320 & \\
Senior (55-64) & -0.4670 & -0.5459 & -0.4456 & -0.4300 & \\
\hline
\end{tabular}

Source: author's calculations. March CPS, 1994-2013. Wage penalties computed from regressions in Table 5. Additional control variables also include binary variables for native-born Hispanic and non-Hispanic African-Americans of the thirdor higher-generation immigrants, second-generation immigrants, cohort effects, educational status (11 years or less, $13-$ 15 years, 16 years, 17 years or more), experience (binary variables for each 5-year interval from 6 to 35 years, plus a binary variable for more than 36 years of experience), marital status, region, size of city, health status, and year fixed effects. All penalties are significant at $p<0.01$

Hispanic African-Americans. Specifically, the penalties for these age-on-arrival groups are $19.5,25.5$, and $31.1 \%$, respectively.

The three largest black male immigrant cohorts are 1975-1981, 1982-1991, and 19922001. First-generation wage penalties for these cohorts are presented in Table 7. The penalties are obtained from the "Full" specification results presented in Table 5. Hence, the penalties for the 1982-1991 cohort of Table 7 are the same as those of column 1 of Table 6. For all groups and all ages of arrival, the penalties rise slightly between the 1970s and 1980s and cohorts and decrease slightly between the 1980s and 1990s cohorts. So there is only a modest decrease in penalties between the 1975-1981 and 1992-2001 cohorts. For example, the wage penalties for Caribbean-English and African-English emerging adults were 21.3 and $32.2 \%$ for the 1970 s cohort, but 20 and $30.9 \%$, respectively, for the 1990s cohort. For the same age group, the Caribbean-Spanish, Haiti, and AfricanFrench penalties were 30.8, 37.4, and 43.4\%, respectively, for the 1975-1981 cohort but $29.5,36.1,42.1 \%$, respectively, for the 1992-2001 cohort.

Wage assimilation is dissimilar between those arriving as children and those arriving at a later age. For the 1975-1981 cohort of Caribbean-English and Haitian immigrants, the wage penalties for persons arriving as children were 9.69 and $25.8 \%$, respectively, while the wage penalties for persons arriving as emerging adults were 21.3 and $37.4 \%$, respectively. So $\Delta \delta_{a}=11.56$ percentage point reduction in the wage penalty over 15 years for these immigrants. For the 18 years between emerging adults and advanced adults, for both Caribbean-English and Haitian, $\Delta \delta_{a}=20.04$ percentage points.

Wage assimilation is similar for adolescents and emerging adults. For the 19821991 cohort of Caribbean-Spanish and African-English immigrants, $\Delta \delta_{a}=19.6 \%$ for the 15 years between men arriving as adolescents and those who arrived as young adults. For the 18 years between emerging adults and advanced adults, the Caribbean-Spanish and African wage penalties decline by 20.4 percentage points.

There is substantial wage assimilation for black male immigrants according to length of time in the USA. For the 1992-2001 cohort of Other immigrants, $\Delta \delta_{a}=34.4$ percentage points when comparing men arriving as middle-age adults and those who arrived as children. For the 43 years between child arrivals and middle-age arrivals, the Other immigrants wage penalty falls from $51.5 \%$ to 17.1 points. 
Table 7 Estimates of wage penalty, by age-on-arrival, cohort, and ethnicity (selected coefficients)

\begin{tabular}{|c|c|c|c|c|c|c|c|}
\hline & $\begin{array}{l}\text { Caribbean- } \\
\text { English }\end{array}$ & $\begin{array}{l}\text { Caribbean- } \\
\text { Spanish }\end{array}$ & Haiti & $\begin{array}{l}\text { African- } \\
\text { English }\end{array}$ & $\begin{array}{l}\text { African- } \\
\text { French }\end{array}$ & $\begin{array}{l}\text { African- } \\
\text { Other }\end{array}$ & $\begin{array}{l}\text { Other } \\
\text { immig. }\end{array}$ \\
\hline \multicolumn{8}{|l|}{ Arrived 1992-2001 } \\
\hline Child $(\leq 12)$ & -0.0839 & -0.1790 & -0.2450 & -0.1930 & -0.3050 & -0.2450 & -0.1710 \\
\hline Adolescent (13-17) & -0.1434 & -0.2385 & -0.3045 & -0.2525 & -0.3645 & -0.3045 & -0.2305 \\
\hline Emerging adult (18-25) & -0.1995 & -0.2946 & -0.3606 & -0.3086 & -0.4206 & -0.3606 & -0.2866 \\
\hline Young adult (26-34) & -0.3389 & -0.4340 & -0.5000 & -0.4480 & -0.5600 & -0.5000 & -0.4260 \\
\hline Advanced adult (35-44) & -0.3999 & -0.4950 & -0.5610 & -0.5090 & -0.6210 & -0.5610 & -0.4870 \\
\hline Middle-age (45-54) & -0.4279 & -0.5230 & -0.5890 & -0.5370 & -0.6490 & -0.5890 & -0.5150 \\
\hline Senior (55-64) & -0.3559 & -0.4510 & -0.5170 & -0.4650 & -0.5770 & -0.5170 & -0.4430 \\
\hline \multicolumn{8}{|l|}{ Arrived 1982-1991 } \\
\hline Child $(\leq 12)$ & -0.1079 & -0.2030 & -0.2690 & -0.2170 & -0.3290 & -0.2690 & -0.1950 \\
\hline Adolescent (13-17) & -0.1674 & -0.2625 & -0.3285 & -0.2765 & -0.3885 & -0.3285 & -0.2545 \\
\hline Emerging adult (18-25) & -0.2235 & -0.3186 & -0.3846 & -0.3326 & -0.4446 & -0.3846 & -0.3106 \\
\hline Young adult (26-34) & -0.3629 & -0.4580 & -0.5240 & -0.4720 & -0.5840 & -0.5240 & -0.4500 \\
\hline Advanced adult (35-44) & -0.4239 & -0.5190 & -0.5850 & -0.5330 & -0.6450 & -0.5850 & -0.5110 \\
\hline Middle-age (45-54) & -0.4519 & -0.5470 & -0.6130 & -0.5610 & -0.6730 & -0.6130 & -0.5390 \\
\hline Senior (55-64) & -0.3799 & -0.4750 & -0.5410 & -0.4890 & -0.6010 & -0.5410 & -0.4670 \\
\hline \multicolumn{8}{|l|}{ Arrived 1975-1981 } \\
\hline Child $(\leq 12)$ & -0.0969 & -0.1920 & -0.2580 & -0.2060 & -0.3180 & -0.2580 & -0.1840 \\
\hline Adolescent (13-17) & -0.1564 & -0.2515 & -0.3175 & -0.2655 & -0.3775 & -0.3175 & -0.2435 \\
\hline Emerging adult (18-25) & -0.2125 & -0.3076 & -0.3736 & -0.3216 & -0.4336 & -0.3736 & -0.2996 \\
\hline Young adult (26-34) & -0.3519 & -0.4470 & -0.5130 & -0.4610 & -0.5730 & -0.5130 & -0.4390 \\
\hline Advanced adult (35-44) & -0.4129 & -0.5080 & -0.5740 & -0.5220 & -0.6340 & -0.5740 & -0.5000 \\
\hline Middle-age (45-54) & -0.4409 & -0.5360 & -0.6020 & -0.5500 & -0.6620 & -0.6020 & -0.5280 \\
\hline Senior (55-64) & -0.3689 & -0.4640 & -0.5300 & -0.4780 & -0.5900 & -0.5300 & -0.4560 \\
\hline
\end{tabular}

Source: author's calculations. March CPS, 1994-2013. Wage penalties computed from regressions in Table 5. Additional control variables also include binary variables for native-born Hispanic and non-Hispanic African-Americans of the thirdor higher-generation immigrants, second-generation immigrants, educational status (11 years or less, 13-15 years, 16 years, 17 years or more), experience (binary variables for each 5-year interval from 6 to 35 years, plus a binary variable for more than 36 years of experience), marital status, region, size of city, health status, and year fixed effects. All differentials are significant at $p<0.01$

Age of arrival is important for assimilation. The "Full" specification of Table 5 shows that native-born non-Hispanic African-American males have a wage penalty of about $20 \%$ relative to white males. No group arriving as adults, that is, age $\geq$ 18 , ever has a lower wage penalty than native-born non-Hispanic AfricanAmericans, and only 18-25-year old Caribbean-English are able to catch up. For all the three cohorts, Caribbean-English arriving as children are an exception; they have wage penalties near $10 \%$. All Other immigrants arriving as children or as adolescents have wage penalties within the 12.7-19.9 \% range of third- and highergeneration African-Americans or much larger wage penalties.

\subsection{Assimilation by education group}

Table 8 provides selected coefficients when the labor market is segregated by skill. Unskilled workers are those with no more than 12 years of education, that is, high school-equivalent education, and skilled workers are those with 13 or more years 
Table 8 Wage inequality by skill group (selected coefficients)

\begin{tabular}{|c|c|c|}
\hline & Education $\leq 12$ & Education $>12$ \\
\hline \multirow[t]{3}{*}{ Non-Hispanic generation 3+ } & $-0.186^{* * *}$ & $-0.204^{* * *}$ \\
\hline & {$[0.0045]$} & {$[0.0043]$} \\
\hline & $(32,948)$ & $(30,237)$ \\
\hline \multirow[t]{3}{*}{ Hispanic generation 3+ } & $-0.0935^{* * *}$ & $-0.163^{* * *}$ \\
\hline & {$[0.0279]$} & {$[0.0324]$} \\
\hline & (670) & (516) \\
\hline \multirow[t]{3}{*}{ Caribbean-English 2} & $-0.151^{* * *}$ & $-0.132^{* * *}$ \\
\hline & {$[0.0420]$} & {$[0.0306]$} \\
\hline & (277) & (546) \\
\hline \multirow[t]{3}{*}{ Caribbean-Spanish 2} & -0.0633 & $-0.143^{* * *}$ \\
\hline & {$[0.0616]$} & {$[0.0469]$} \\
\hline & (157) & (216) \\
\hline \multirow[t]{3}{*}{ Haiti 2} & -0.0178 & $-0.237^{* * *}$ \\
\hline & {$[0.0841]$} & {$[0.0685]$} \\
\hline & (87) & (151) \\
\hline \multirow[t]{3}{*}{ African 2-English } & -0.201 & $-0.165^{* * *}$ \\
\hline & {$[0.1358]$} & {$[0.0553]$} \\
\hline & $(42)$ & (171) \\
\hline \multirow[t]{3}{*}{ African 2-non-English } & $-0.183^{*}$ & 0.0711 \\
\hline & {$[0.1060]$} & {$[0.0886]$} \\
\hline & (37) & \\
\hline \multirow[t]{3}{*}{ Other immigrants 2} & $-0.145^{* * *}$ & $-0.123^{* * *}$ \\
\hline & {$[0.0454]$} & {$[0.0285]$} \\
\hline & (336) & $(501)$ \\
\hline \multirow[t]{3}{*}{ Caribbean-English } & 0.0222 & $-0.183^{* * *}$ \\
\hline & {$[0.0270]$} & [0.0299] \\
\hline & $(1361)$ & (1396) \\
\hline \multirow[t]{3}{*}{ Caribbean-Spanish } & $-0.0688^{* *}$ & $-0.296^{* * *}$ \\
\hline & {$[0.0303]$} & {$[0.0430]$} \\
\hline & $(767)$ & (370) \\
\hline \multirow[t]{3}{*}{ Haiti } & $-0.137^{* * *}$ & $-0.358^{* * *}$ \\
\hline & {$[0.0319]$} & {$[0.0356]$} \\
\hline & (757) & (650) \\
\hline \multirow[t]{3}{*}{ African-English } & -0.0339 & $-0.282^{* * *}$ \\
\hline & {$[0.0430]$} & {$[0.0294]$} \\
\hline & (309) & $(1222)$ \\
\hline \multirow[t]{3}{*}{ African-French } & -0.0706 & $-0.432^{* * *}$ \\
\hline & [0.1259] & {$[0.0866]$} \\
\hline & (17) & (57) \\
\hline \multirow[t]{3}{*}{ African-Other language } & $-0.11^{* * *}$ & $-0.342^{* * *}$ \\
\hline & {$[0.0367]$} & {$[0.0320]$} \\
\hline & (555) & (957) \\
\hline
\end{tabular}


Table 8 Wage inequality by skill group (selected coefficients) (Continued)

\begin{tabular}{|c|c|c|}
\hline \multirow[t]{3}{*}{ Other immigrants } & $-0.0533^{* *}$ & $-0.294^{* * *}$ \\
\hline & {$[0.0257]$} & {$[0.0355]$} \\
\hline & $(1140)$ & (836) \\
\hline \multirow[t]{2}{*}{ Arrived pre-1965 } & $-0.2^{* * *}$ & $-0.0869^{* *}$ \\
\hline & {$[0.0360]$} & {$[0.0378]$} \\
\hline \multirow[t]{2}{*}{ Arrived 1965-1974 } & $-0.187^{* * *}$ & $-0.163^{* * *}$ \\
\hline & {$[0.0342]$} & {$[0.0360]$} \\
\hline \multirow[t]{2}{*}{ Arrived 1975-1981 } & $-0.172^{* * *}$ & $-0.136^{* * *}$ \\
\hline & {$[0.0326]$} & [0.0349] \\
\hline \multirow[t]{2}{*}{ Arrived 1982-1991 } & $-0.2^{* * *}$ & $-0.149^{* * *}$ \\
\hline & {$[0.0312]$} & [0.0322] \\
\hline \multirow[t]{2}{*}{ Arrived 1992-2001 } & $-0.159^{* * *}$ & $-0.153^{* * *}$ \\
\hline & {$[0.0312]$} & [0.0336] \\
\hline \multirow[t]{2}{*}{ Arrived 2002-2007 } & $-0.128^{* * *}$ & $-0.158^{* * *}$ \\
\hline & {$[0.0375]$} & {$[0.0408]$} \\
\hline \multirow[t]{2}{*}{ Arrived 2008-2013 } & -0.0985 & $-0.206^{* * *}$ \\
\hline & {$[0.0680]$} & {$[0.0673]$} \\
\hline \multirow[t]{2}{*}{ Child $(\leq 12)$} & $0.154^{* * *}$ & $0.0873^{* *}$ \\
\hline & {$[0.0325]$} & {$[0.0347]$} \\
\hline \multirow[t]{2}{*}{ Adolescent (13-17) } & $0.0902^{* *}$ & 0.0529 \\
\hline & {$[0.0357]$} & [0.0389] \\
\hline \multirow[t]{2}{*}{ Emerging adult (18-25) } & 0.000852 & 0.0478 \\
\hline & [0.0303] & {$[0.0318]$} \\
\hline \multirow[t]{2}{*}{ Young adult (26-34) } & $-0.107^{* * *}$ & $-0.097^{* * *}$ \\
\hline & {$[0.0320]$} & {$[0.0329]$} \\
\hline \multirow[t]{2}{*}{ Advanced adult (35-44) } & $-0.168^{* * *}$ & $-0.144^{* * *}$ \\
\hline & {$[0.0376]$} & {$[0.0406]$} \\
\hline \multirow[t]{2}{*}{ Middle-age (45-54) } & $-0.105^{* *}$ & $-0.265^{* * *}$ \\
\hline & {$[0.0491]$} & {$[0.0560]$} \\
\hline \multirow[t]{2}{*}{ Senior (55-64) } & $-0.212^{* *}$ & -0.0884 \\
\hline & {$[0.1070]$} & {$[0.2465]$} \\
\hline$R$-sq & 0.4064 & 0.3427 \\
\hline N & 298,501 & 405,296 \\
\hline
\end{tabular}

Source: author's calculations. March CPS, 1994-2013. Additional control variables also include citizenship status, educational status (11 years or less, 13-15 years, 16 years, 17 years or more), experience (binary variables for each 5-year interval from 6 to 35 years, plus a binary variable for more than 36 years of experience) or age, age ${ }^{2}$, age ${ }^{3}$, marital status, region, size of city, health status, year fixed effects, state fixed effects, and state*trend interaction effects. Robust standard errors are reported in brackets. Numbers of observations within cell are reported in parentheses

of education, that is, college-equivalent education. Given the small number of observations for some groups, several of these coefficients are not measured precisely. The numbers of observations for each immigrant group are included in parenthesis beneath the standard errors. There is considerable wage improvement between first- and second-generation black immigrants with college-equivalent education. For first-generation immigrants, the most rapid wage assimilation is located among unskilled immigrants arriving as children and adolescents, most especially 
Caribbean-English and African-English immigrants. No group of first-generation skilled immigrants obtains wage parity with native-born African-Americans.

Second-generation Caribbean-English and Other immigrants have sizable wage differentials for both unskilled and skilled workers. Both unskilled secondgeneration Caribbean-English and unskilled Other immigrants have a wage penalty of about $15 \%$. College-equivalent second-generation Caribbean-English and Other immigrants earn 13 and $12 \%$ less, respectively, than otherwise identical white males. Both sets of wage differentials are lower than the 18.6 and $20.4 \%$ penalties for high school and college-equivalent third- and higher-generation non-Hispanic black males, respectively.

College-equivalent second-generation Haitian immigrants have a wage penalty of $23.7 \%$. Second-generation African-Non-English immigrants have an imprecisely measured premium of $7.11 \%$. But there are just 53 observations for this group. Among men with more than 12 years of education, second-generation CaribbeanSpanish and African-English immigrants earn 14.3 and $16.5 \%$ less, respectively, than similarly educated white males. Hence, except for Haitian immigrants, second-generation skilled black immigrants have a large wage penalty that is moderately lower than the wage penalty for African-Americans without recent immigrant roots.

No group of skilled black immigrants has a wage differential equal to or lower than native-born African-Americans (Table 9b), regardless of age of arrival or cohort. For example, Caribbean-English who arrive in the USA as children are the most assimilated group. Yet they have wage penalties of $24.5 \%$ (1980s and 1990s cohorts) and $25.4 \%$ (2000s cohort). African-French immigrants experience the least labor market assimilation; even those who arrive in the USA as children have wage differentials that are about $0.50 \log$ points lower than college-equivalent white males.

The age-on-arrival effects are larger (in absolute value) for college-equivalent immigrants than they are for high school-equivalent workers (Table 9a). Consider the 1982-1991 cohort. Unskilled Caribbean-English immigrants arriving as children and emerging adults have wage penalties of 2.38 and $17.69 \%$, respectively, a 15 percentage reduction in the wage differential over a period of about 15 years. But skilled Caribbean-English immigrants have wage premiums of 28.4 and $24.5 \%$, respectively, a 4 percentage point reduction in the wage differential over a period of about 15 years. Unskilled black immigrants arriving as advanced adults and middle-age have wage penalties of 12 and $14 \%$, respectively, but skilled black immigrants have wage penalties of 12.6 and $22.7 \%$, respectively.

\section{Conclusions}

This study improves on the previous literature in several ways. One, we incorporate the ethnic and nativity diversity among African-Americans into the study of labor market assimilation of black immigrants. Specifically, we strictly identify third- or higher-generation African-Americans (both non-Hispanic and Hispanic) and second-generation black immigrants as distinct groups from first-generation black immigrants. We include black immigrants from throughout the Caribbean, Africa, and the rest of the world. Two, we separately analyze period effects, cohort effects, and age-on-arrival effects for black immigrants. Our analysis of duration 
Table 9 Estimates of wage penalty for unskilled and skilled black male immigrants, by age-onarrival, cohort, and ethnicity (selected coefficients)

\begin{tabular}{|c|c|c|c|c|c|c|c|}
\hline & $\begin{array}{l}\text { Caribbean- } \\
\text { English }\end{array}$ & $\begin{array}{l}\text { Caribbean- } \\
\text { Spanish }\end{array}$ & Haiti & $\begin{array}{l}\text { African- } \\
\text { English }\end{array}$ & $\begin{array}{l}\text { African- } \\
\text { French }\end{array}$ & $\begin{array}{l}\text { African- } \\
\text { Other }\end{array}$ & $\begin{array}{l}\text { Other } \\
\text { immig. }\end{array}$ \\
\hline \multicolumn{8}{|l|}{ a. } \\
\hline \multicolumn{8}{|l|}{ Arrived 1982-1991 } \\
\hline Child $(\leq 12)$ & -0.0238 & -0.1148 & -0.1830 & -0.0799 & -0.1166 & -0.1560 & -0.0993 \\
\hline Adolescent (13-17) & -0.0876 & -0.1786 & -0.2468 & -0.1437 & -0.1804 & -0.2198 & -0.1631 \\
\hline Emerging adult (18-25) & -0.1769 & -0.2679 & -0.3361 & -0.2330 & -0.2697 & -0.3091 & -0.2524 \\
\hline Young adult (26-34) & -0.2848 & -0.3758 & -0.4440 & -0.3409 & -0.3776 & -0.4170 & -0.3603 \\
\hline Advanced adult (35-44) & -0.3458 & -0.4368 & -0.5050 & -0.4019 & -0.4386 & -0.4780 & -0.4213 \\
\hline Middle-age (45-54) & -0.2828 & -0.3738 & -0.4420 & -0.3389 & -0.3756 & -0.4150 & -0.3583 \\
\hline Senior (55-64) & -0.3898 & -0.4808 & -0.5490 & -0.4459 & -0.4826 & -0.5220 & -0.4653 \\
\hline \multicolumn{8}{|l|}{ Arrived 1992-2001 } \\
\hline Child $(\leq 12)$ & 0.0172 & -0.0738 & -0.1420 & -0.0389 & -0.0756 & -0.1150 & -0.0583 \\
\hline Adolescent (13-17) & -0.0466 & -0.1376 & -0.2058 & -0.1027 & -0.1394 & -0.1788 & -0.1221 \\
\hline Emerging adult (18-25) & -0.1359 & -0.2269 & -0.2951 & -0.1920 & -0.2287 & -0.2681 & -0.2114 \\
\hline Young adult (26-34) & -0.2438 & -0.3348 & -0.4030 & -0.2999 & -0.3366 & -0.3760 & -0.3193 \\
\hline Advanced adult (35-44) & -0.3048 & -0.3958 & -0.4640 & -0.3609 & -0.3976 & -0.4370 & -0.3803 \\
\hline Middle-age (45-54) & -0.2418 & -0.3328 & -0.4010 & -0.2979 & -0.3346 & -0.3740 & -0.3173 \\
\hline Senior (55-64) & -0.3488 & -0.4398 & -0.5080 & -0.4049 & -0.4416 & -0.4810 & -0.4243 \\
\hline \multicolumn{8}{|l|}{ Arrived 2002-2007 } \\
\hline Child $(\leq 12)$ & 0.0482 & -0.0428 & -0.1110 & -0.0079 & -0.0446 & -0.0840 & -0.0273 \\
\hline Adolescent (13-17) & -0.0156 & -0.1066 & -0.1748 & -0.0717 & -0.1084 & -0.1478 & -0.0911 \\
\hline Emerging adult (18-25) & -0.1049 & -0.1959 & -0.2641 & -0.1610 & -0.1977 & -0.2371 & -0.1804 \\
\hline Young adult (26-34) & -0.2128 & -0.3038 & -0.3720 & -0.2689 & -0.3056 & -0.3450 & -0.2883 \\
\hline Advanced adult (35-44) & -0.2738 & -0.3648 & -0.4330 & -0.3299 & -0.3666 & -0.4060 & -0.3493 \\
\hline Middle-age (45-54) & -0.2108 & -0.3018 & -0.3700 & -0.2669 & -0.3036 & -0.3430 & -0.2863 \\
\hline Senior (55-64) & -0.3178 & -0.4088 & -0.4770 & -0.3739 & -0.4106 & -0.4500 & -0.3933 \\
\hline \multicolumn{8}{|l|}{ b. } \\
\hline \multicolumn{8}{|l|}{ Arrived 1982-1991 } \\
\hline Child $(\leq 12)$ & -0.2447 & -0.3577 & -0.4197 & -0.3437 & -0.4937 & -0.4037 & -0.3557 \\
\hline Adolescent (13-17) & -0.2791 & -0.3921 & -0.4541 & -0.3781 & -0.5281 & -0.4381 & -0.3901 \\
\hline Emerging adult (18-25) & -0.2842 & -0.3972 & -0.4592 & -0.3832 & -0.5332 & -0.4432 & -0.3952 \\
\hline Young adult (26-34) & -0.4290 & -0.5420 & -0.6040 & -0.5280 & -0.6780 & -0.5880 & -0.5400 \\
\hline Advanced adult (35-44) & -0.4760 & -0.5890 & -0.6510 & -0.5750 & -0.7250 & -0.6350 & -0.5870 \\
\hline Middle-age (45-54) & -0.5970 & -0.7100 & -0.7720 & -0.6960 & -0.8460 & -0.7560 & -0.7080 \\
\hline Senior (55-64) & -0.4204 & -0.5334 & -0.5954 & -0.5194 & -0.6694 & -0.5794 & -0.5314 \\
\hline \multicolumn{8}{|l|}{ Arrived 1992-2001 } \\
\hline Child $(\leq 12)$ & -0.2487 & -0.3617 & -0.4237 & -0.3477 & -0.4977 & -0.4077 & -0.3597 \\
\hline Adolescent (13-17) & -0.2831 & -0.3961 & -0.4581 & -0.3821 & -0.5321 & -0.4421 & -0.3941 \\
\hline Emerging adult (18-25) & -0.2882 & -0.4012 & -0.4632 & -0.3872 & -0.5372 & -0.4472 & -0.3992 \\
\hline Young adult (26-34) & -0.4330 & -0.5460 & -0.6080 & -0.5320 & -0.6820 & -0.5920 & -0.5440 \\
\hline Advanced adult (35-44) & -0.4800 & -0.5930 & -0.6550 & -0.5790 & -0.7290 & -0.6390 & -0.5910 \\
\hline Middle-age (45-54) & -0.6010 & -0.7140 & -0.7760 & -0.7000 & -0.8500 & -0.7600 & -0.7120 \\
\hline Senior (55-64) & -0.4244 & -0.5374 & -0.5994 & -0.5234 & -0.6734 & -0.5834 & -0.5354 \\
\hline
\end{tabular}


Table 9 Estimates of wage penalty for unskilled and skilled black male immigrants, by age-onarrival, cohort, and ethnicity (selected coefficients) (Continued)

\begin{tabular}{llllllll}
\hline Arrived 2002-2007 & & & & & & & \\
Child (<12) & -0.2537 & -0.3667 & -0.4287 & -0.3527 & -0.5027 & -0.4127 & -0.3647 \\
Adolescent (13-17) & -0.2881 & -0.4011 & -0.4631 & -0.3871 & -0.5371 & -0.4471 & -0.3991 \\
Emerging adult (18-25) & -0.2932 & -0.4062 & -0.4682 & -0.3922 & -0.5422 & -0.4522 & -0.4042 \\
Young adult (26-34) & -0.4380 & -0.5510 & -0.6130 & -0.5370 & -0.6870 & -0.5970 & -0.5490 \\
Advanced adult (35-44) & -0.4850 & -0.5980 & -0.6600 & -0.5840 & -0.7340 & -0.6440 & -0.5960 \\
Middle-age (45-54) & -0.6060 & -0.7190 & -0.7810 & -0.7050 & -0.8550 & -0.7650 & -0.7170 \\
Senior (55-64) & -0.4294 & -0.5424 & -0.6044 & -0.5284 & -0.6784 & -0.5884 & -0.5404 \\
\hline
\end{tabular}

Source: author's calculations. March CPS, 1994-2013. Differentials are derived from Table 8. Differentials $=$ ethnic coefficient + age-on-arrival coefficient + cohort coefficient

effects focuses on differences in the ages of arrival of immigrants. Except for Hamilton (2012, 2014), previous analyses of black immigration have ignored period effects and ages of arrival of immigrants. Three, using the 1994-2013 Current Population Survey, Annual Social and Economic Supplement, we have 20 years of data versus most studies which use only a single year of data. Further, the most influential studies to date of black immigrants use data from the 1970s or earlier or the 1980s. The largest cohorts of black immigrants were just entering the USA during the 1980s and 1990s and so were newly assimilating when their outcomes were being studied. This study has a large representation of second-generation immigrants and first-generation immigrants who have worked in the USA for an extremely long period of time. Hence, we are able to establish more robust and nuanced conclusions on labor market assimilation of black immigrants. Five, this study controls for both inter-state and intra-state differences in wage trends. Finally, we separately analyze assimilation by skill groups, and we also check for differences in assimilation according to whether or not a second-generation immigrant's parents include an American.

This study finds that after 10-15 years in the USA, labor market black male immigrants have labor market outcomes very similar to native-born AfricanAmerican males. Second-generation black immigrants also have labor market outcomes that are very similar to native-born African-American males. The labor market outcomes of black immigrants in the USA labor market are not caused by low skill levels among black immigrants. African-American immigrants assimilate within the US labor market, with intergenerational improvement being an important path of labor market assimilation. After living in the USA for 9-15 years, most first-generation black immigrants will have wage penalties at least as large as native-born African-Americans. Second-generation black male immigrants have wage penalties ranging from 9 to $18 \%$, versus wage penalties of $14-17 \%$ for native-born black males.

The results of this study offer a refinement of Hamilton (2014). The wages of Caribbean-English immigrants as a whole do not catch up with and overtake the wages of native-born African-Americans. Rather, the unskilled Caribbean-English and CaribbeanSpanish immigrants who arrive in the USA as children do have wage penalties that are smaller than the third- or higher-generation non-Hispanic African-Americans. 
Concluding, the results of this study are consistent with the notion that the immigration process tends to select black immigrants who have or who would have achieved middle income or higher status in their country of origin. As such, black immigrants tend to have above average observable characteristics. Nevertheless, more research needs to be done to empirically evaluate this hypothesis. Differential treatment in the labor market due to race-specific and ethnic-specific factors as well as nativity may also be important determinants of the labor market assimilation of black immigrants.

\section{Endnotes}

${ }^{1}$ An older literature argued that black immigrants had superior culture relative to that of the native African-American immigrants or that employers preferred black immigrants relative to native African Americans. For details on these hypotheses and their empirical refutation, see the following: Dodoo and Takyi (2002), Model (2008, 1991), Kalmijn (1996), Pierre (2004), Dodoo (1997), Ifatunji (2013a, b).

${ }^{2}$ The coefficients are 0.2662 and 0.1801 , respectively, for cohort effects in a log wage equation.

${ }^{3}$ Cubans are similar to blacks. Asians are similar to whites. Mexicans and other Hispanics have both wage assimilation and decreasing quality (or decreasing treatment).

${ }^{4}$ Ottaviano and Peri (2012) show that workers with less than 12 years of education and high school graduates are perfect substitutes, workers with some college and college graduates have a high elasticity of substitution, and there is a very low elasticity of substitution between all workers with 12 or fewer years of education versus all workers with 13 or more years of education.The detailed national origin figures and associated levels of education are derived from our CPS sample, but not presented in Table 3.

${ }^{5}$ The detailed national origin figures and associated levels of education are derived from our CPS sample, but not presented in Table 3.

${ }^{6}$ Unless an alternative source is specified, all source country education statistics are from World Factbook, 2013.

${ }^{7}$ This figure is derived from a wage regression using Jamaican census data. Each additional year of education yields a $4.9 \%$ increase in earnings. A person with 12.90 years of education in Jamaica would also have passed the Caribbean Examinations Council (CXC) Basic education, a high stakes exam, which has an additional premium of $17.75 \%$. Beyond the CXC Basic examination are additional high stakes examinations. Persons passing 1-3 subject areas of the GCEO would earn additional $26.21 \%$ increase in earnings. This is the lower bound. The upper bound estimate assumes the person would have passed 4 subject area examinations of the GCEO (49.23\% premium) plus the GCEA examination (49.14\% premium).

${ }^{8} \mathrm{We}$ also estimated this equation with linear and quadratic duration effects. An $F$ test fails to reject the null hypothesis that these variables are jointly insignificant. 


\section{Appendix}

Table 10 Male annual earnings inequality: race, immigrant ethnicity, and age at arrival (selected coefficients)

\begin{tabular}{|c|c|c|c|c|c|c|c|}
\hline & Exper & Age & Afr lang & Educ & State & All & Full \\
\hline \multirow{2}{*}{$\begin{array}{l}\text { Non-Hispanic } \\
\text { generation 3+ }\end{array}$} & $-0.203^{* * *}$ & $-0.227^{* * *}$ & $-0.227^{* * *}$ & $-0.227^{* * *}$ & $-0.243^{* * *}$ & $-0.243^{* * *}$ & $-0.242^{* * *}$ \\
\hline & {$[0.0040]$} & [0.0039] & [0.0039] & [0.0039] & {$[0.0040]$} & {$[0.0040]$} & {$[0.0040]$} \\
\hline \multirow[t]{2}{*}{ Hispanic generation 3+ } & $-0.12^{* * *}$ & $-0.127^{* * *}$ & $-0.127^{* * *}$ & $-0.127^{* * *}$ & $-0.133^{* * *}$ & $-0.133^{* * *}$ & $-0.135^{* * *}$ \\
\hline & {$[0.0273]$} & {$[0.0264]$} & {$[0.0264]$} & {$[0.0264]$} & {$[0.0264]$} & {$[0.0264]$} & {$[0.0264]$} \\
\hline \multirow[t]{2}{*}{ Caribbean-English 2} & $-0.182^{* * *}$ & $-0.207^{* * *}$ & $-0.207^{* * *}$ & $-0.207^{* * *}$ & $-0.214^{* * *}$ & $-0.214^{* * *}$ & $-0.213^{* * *}$ \\
\hline & {$[0.0380]$} & {$[0.0358]$} & {$[0.0358]$} & {$[0.0358]$} & {$[0.0358]$} & {$[0.0358]$} & {$[0.0358]$} \\
\hline \multirow[t]{2}{*}{ Caribbean-Spanish 2} & $-0.178^{* * *}$ & $-0.164^{* * *}$ & $-0.164^{* * *}$ & $-0.164^{* * *}$ & $-0.172^{* * *}$ & $-0.172^{* * *}$ & $-0.174^{* * *}$ \\
\hline & {$[0.0511]$} & {$[0.0489]$} & [0.0489] & [0.0489] & {$[0.0489]$} & {$[0.0489]$} & {$[0.0490]$} \\
\hline \multirow[t]{2}{*}{ Haiti 2} & $-0.192^{* *}$ & $-0.186^{* *}$ & $-0.186^{* *}$ & $-0.187^{* *}$ & $-0.179 * *$ & $-0.179 * *$ & $-0.179^{* *}$ \\
\hline & {$[0.0771]$} & {$[0.0760]$} & {$[0.0760]$} & {$[0.0760]$} & {$[0.0758]$} & {$[0.0758]$} & {$[0.0758]$} \\
\hline \multirow[t]{2}{*}{ African 2} & $-0.213^{* * *}$ & $-0.24^{* * *}$ & & $-0.239^{* * *}$ & $-0.264^{* * *}$ & & \\
\hline & {$[0.0668]$} & [0.0639] & & [0.0639] & {$[0.0641]$} & & \\
\hline \multirow[t]{2}{*}{ African-English 2} & & & $-0.23^{* * *}$ & & & $-0.248^{* * *}$ & $-0.254^{* * *}$ \\
\hline & & & {$[0.0722]$} & & & {$[0.0725]$} & {$[0.0726]$} \\
\hline \multirow[t]{2}{*}{ African-Non-English 2} & & & $-0.266^{* *}$ & & & $-0.298^{* *}$ & $-0.296^{* *}$ \\
\hline & & & {$[0.1305]$} & & & [0.1309] & [0.1298] \\
\hline \multirow[t]{2}{*}{ Other immigrants 2} & $-0.13^{* * *}$ & $-0.134^{* * *}$ & $-0.134^{* * *}$ & $-0.134^{* * *}$ & $-0.146^{* * *}$ & $-0.145^{* * *}$ & $-0.146^{* * *}$ \\
\hline & {$[0.0338]$} & {$[0.0320]$} & {$[0.0320]$} & [0.0320] & {$[0.0320]$} & {$[0.0320]$} & {$[0.0319]$} \\
\hline \multirow[t]{2}{*}{ Citizen } & -0.0174 & $0.0326^{*}$ & $0.0325^{*}$ & $0.036^{*}$ & $0.0332^{*}$ & $0.0364^{* *}$ & $0.0368^{* *}$ \\
\hline & [0.0188] & [0.0183] & [0.0183] & {$[0.0185]$} & {$[0.0183]$} & {$[0.0185]$} & {$[0.0185]$} \\
\hline \multirow[t]{2}{*}{ Caribbean-English } & $-0.0857^{* * *}$ & $-0.0803^{* * *}$ & $-0.0802^{* * *}$ & $-0.0864^{* * *}$ & $-0.0818^{* * *}$ & $-0.0889^{* * *}$ & $-0.09^{* * *}$ \\
\hline & {$[0.0228]$} & {$[0.0221]$} & {$[0.0221]$} & {$[0.0248]$} & {$[0.0222]$} & {$[0.0249]$} & {$[0.0249]$} \\
\hline \multirow[t]{2}{*}{ Caribbean-Spanish } & $-0.0959^{* * *}$ & $-0.136^{* * *}$ & $-0.136^{* * *}$ & $-0.143^{* * *}$ & $-0.146^{* * *}$ & $-0.153^{* * *}$ & $-0.153^{* * *}$ \\
\hline & {$[0.0305]$} & {$[0.0289]$} & {$[0.0289]$} & {$[0.0305]$} & [0.0289] & {$[0.0305]$} & {$[0.0305]$} \\
\hline \multirow[t]{2}{*}{ Haiti } & $-0.25^{* * *}$ & $-0.257^{* * *}$ & $-0.257^{* * *}$ & $-0.263^{* * *}$ & $-0.246^{* * *}$ & $-0.253^{* * *}$ & $-0.254^{* * *}$ \\
\hline & {$[0.0295]$} & {$[0.0285]$} & {$[0.0285]$} & {$[0.0300]$} & {$[0.0286]$} & {$[0.0300]$} & {$[0.0300]$} \\
\hline \multirow[t]{2}{*}{ African } & $-0.238^{* * *}$ & $-0.219^{* * *}$ & & $-0.22^{* * *}$ & $-0.236^{* * *}$ & & \\
\hline & {$[0.0236]$} & {$[0.0228]$} & & {$[0.0243]$} & {$[0.0229]$} & & \\
\hline \multirow[t]{2}{*}{ African-English } & & & $-0.201^{* * *}$ & & & $-0.218^{* * *}$ & $-0.219^{* * *}$ \\
\hline & & & {$[0.0275]$} & & & {$[0.0289]$} & [0.0289] \\
\hline \multirow[t]{2}{*}{ African-French } & & & $-0.361^{* * *}$ & & & $-0.373^{* * *}$ & $-0.374^{* * *}$ \\
\hline & & & {$[0.0853]$} & & & {$[0.0865]$} & {$[0.0861]$} \\
\hline \multirow[t]{2}{*}{ African-Other lang. } & & & $-0.231^{* * *}$ & & & $-0.252^{* * *}$ & $-0.252^{* * *}$ \\
\hline & & & {$[0.0284]$} & & & {$[0.0297]$} & {$[0.0298]$} \\
\hline \multirow[t]{2}{*}{ Other immigrants } & $-0.0938^{* * *}$ & $-0.134^{* * *}$ & $-0.134^{* * *}$ & $-0.139^{* * *}$ & $-0.139^{* * *}$ & $-0.145^{* * *}$ & $-0.145^{* * *}$ \\
\hline & {$[0.0264]$} & {$[0.0255]$} & {$[0.0255]$} & {$[0.0265]$} & {$[0.0255]$} & {$[0.0265]$} & {$[0.0266]$} \\
\hline \multirow[t]{2}{*}{ Arrived pre-1965 } & -0.0462 & $-0.159^{* * *}$ & $-0.159^{* * *}$ & $-0.154^{* * *}$ & $-0.158^{* * *}$ & $-0.152^{* * *}$ & $-0.153^{* * *}$ \\
\hline & {$[0.0317]$} & {$[0.0310]$} & {$[0.0310]$} & {$[0.0321]$} & [0.0310] & {$[0.0321]$} & {$[0.0321]$} \\
\hline \multirow[t]{2}{*}{ Arrived 1965-1974 } & $-0.0727^{* *}$ & $-0.224^{* * *}$ & $-0.225^{* * *}$ & $-0.22^{* * *}$ & $-0.229^{* * *}$ & $-0.223^{* * *}$ & $-0.223^{* * *}$ \\
\hline & {$[0.0311]$} & [0.0303] & {$[0.0303]$} & {$[0.0312]$} & {$[0.0303]$} & {$[0.0312]$} & {$[0.0312]$} \\
\hline
\end{tabular}


Table 10 Male annual earnings inequality: race, immigrant ethnicity, and age at arrival (selected coefficients) (Continued)

\begin{tabular}{|c|c|c|c|c|c|c|c|}
\hline \multirow[t]{2}{*}{ Arrived 1975-1981 } & $-0.058^{*}$ & $-0.183^{* * *}$ & $-0.183^{* * *}$ & $-0.179 * * *$ & $-0.185^{* * *}$ & $-0.181^{* * *}$ & $-0.181^{* * *}$ \\
\hline & {$[0.0301]$} & {$[0.0294]$} & {$[0.0293]$} & [0.0299] & {$[0.0294]$} & {$[0.0299]$} & [0.0299] \\
\hline \multirow[t]{2}{*}{ Arrived 1982-1991 } & $-0.116^{* * *}$ & $-0.207^{* * *}$ & $-0.207^{* * *}$ & $-0.205^{* * *}$ & $-0.212^{* * *}$ & $-0.208^{* * *}$ & $-0.209^{* * *}$ \\
\hline & {$[0.0282]$} & {$[0.0276]$} & {$[0.0276]$} & [0.0283] & {$[0.0276]$} & {$[0.0283]$} & {$[0.0283]$} \\
\hline \multirow[t]{2}{*}{ Arrived 1992-2001 } & $-0.118^{* * *}$ & $-0.187^{* * *}$ & $-0.187^{* * *}$ & $-0.186^{* * *}$ & $-0.189^{* * *}$ & $-0.187^{* * *}$ & $-0.186^{* * *}$ \\
\hline & {$[0.0292]$} & {$[0.0286]$} & {$[0.0286]$} & {$[0.0292]$} & {$[0.0287]$} & {$[0.0292]$} & {$[0.0292]$} \\
\hline \multirow[t]{2}{*}{ Arrived 2002-2007 } & $-0.123^{* * *}$ & $-0.179 * * *$ & $-0.178^{* * *}$ & $-0.178^{* * *}$ & $-0.183^{* * *}$ & $-0.181^{* * *}$ & $-0.182^{* * *}$ \\
\hline & {$[0.0358]$} & {$[0.0350]$} & {$[0.0350]$} & {$[0.0355]$} & {$[0.0350]$} & {$[0.0356]$} & {$[0.0356]$} \\
\hline \multirow[t]{2}{*}{ Arrived 2008-2013 } & $-0.263^{* * *}$ & $-0.341^{* * *}$ & $-0.337^{* * *}$ & $-0.34^{* * *}$ & $-0.346^{* * *}$ & $-0.342^{* * *}$ & $-0.346^{* * *}$ \\
\hline & {$[0.0650]$} & {$[0.0625]$} & {$[0.0625]$} & {$[0.0628]$} & {$[0.0622]$} & {$[0.0626]$} & {$[0.0625]$} \\
\hline \multirow[t]{2}{*}{ Child $(\leq 12)$} & $0.0586^{* *}$ & $0.161^{* * *}$ & $0.161^{* * *}$ & $0.156^{* * *}$ & $0.158^{* * *}$ & $0.152^{* * *}$ & $0.152^{* * *}$ \\
\hline & {$[0.0293]$} & {$[0.0286]$} & {$[0.0286]$} & [0.0299] & {$[0.0286]$} & {$[0.0300]$} & {$[0.0300]$} \\
\hline \multirow[t]{2}{*}{ Adolescent (13-17) } & $0.0989^{* * *}$ & $0.133^{* * *}$ & $0.133^{* * *}$ & $0.125^{* * *}$ & $0.129^{* * *}$ & $0.121^{* * *}$ & $0.121^{* * *}$ \\
\hline & {$[0.0316]$} & [0.0308] & {$[0.0308]$} & {$[0.0330]$} & {$[0.0309]$} & [0.0330] & {$[0.0330]$} \\
\hline \multirow[t]{2}{*}{ Emerging adult (18-25) } & $0.0488^{*}$ & $0.0693^{* *}$ & $0.069^{* *}$ & $0.0714^{* *}$ & $0.0663^{* *}$ & $0.068^{* *}$ & $0.0677^{* *}$ \\
\hline & {$[0.0282]$} & {$[0.0275]$} & {$[0.0276]$} & {$[0.0278]$} & {$[0.0276]$} & {$[0.0278]$} & {$[0.0278]$} \\
\hline \multirow[t]{2}{*}{ Young adult (26-34) } & $-0.09^{* * *}$ & $-0.109^{* * *}$ & $-0.108^{* * *}$ & $-0.109^{* * *}$ & $-0.113^{* * *}$ & $-0.112^{* * *}$ & $-0.111^{* * *}$ \\
\hline & {$[0.0297]$} & [0.0290] & {$[0.0290]$} & [0.0291] & {$[0.0291]$} & {$[0.0291]$} & {$[0.0291]$} \\
\hline \multirow[t]{2}{*}{ Advanced adult (35-44) } & $-0.12^{* * *}$ & $-0.134^{* * *}$ & $-0.135^{* * *}$ & $-0.134^{* * *}$ & $-0.136^{* * *}$ & $-0.137^{* * *}$ & $-0.135^{* * *}$ \\
\hline & {$[0.0351]$} & {$[0.0343]$} & {$[0.0343]$} & {$[0.0343]$} & {$[0.0343]$} & {$[0.0343]$} & {$[0.0343]$} \\
\hline \multirow[t]{2}{*}{ Middle-age (45-54) } & $-0.178^{* * *}$ & $-0.149^{* * *}$ & $-0.15^{* * *}$ & $-0.148^{* * *}$ & $-0.153^{* * *}$ & $-0.153^{* * *}$ & $-0.151^{* * *}$ \\
\hline & {$[0.0496]$} & {$[0.0474]$} & {$[0.0475]$} & {$[0.0475]$} & {$[0.0475]$} & {$[0.0475]$} & {$[0.0475]$} \\
\hline \multirow[t]{2}{*}{ Senior (55-64) } & -0.073 & -0.131 & -0.128 & -0.129 & -0.124 & -0.12 & -0.116 \\
\hline & {$[0.1456]$} & {$[0.1367]$} & {$[0.1368]$} & {$[0.1367]$} & {$[0.1381]$} & [0.1381] & [0.1384] \\
\hline$R$-sq & 0.4427 & 0.4734 & 0.4734 & 0.4734 & 0.4753 & 0.4753 & 0.4759 \\
\hline N & 703,867 & 703,867 & 703,867 & 703,867 & 703,867 & 703,867 & 703,867 \\
\hline
\end{tabular}

Source: author's calculations. March CPS, 1994-2013. Additional control variables also include citizenship status, educational status (11 years or less, 13-15 years, 16 years, 17 years or more), experience (binary variables for each 5-year interval from 6 to 35 years, plus a binary variable for more than 36 years of experience), age, age ${ }^{2}$, age ${ }^{3}$, marital status, region, size of city, health status, year fixed effects, state fixed effects, and state*trend interaction effects. Robust standard errors are reported in parentheses ${ }^{*} p<0.10 ;{ }^{* *} p<0.05 ;{ }^{* * *} p<0.01$ 
Table 11 Male hourly wage inequality: race, immigrant ethnicity, and age at arrival (selected coefficients), age $\geq 25$

\begin{tabular}{|c|c|c|c|c|c|c|c|}
\hline & Exper & Age & Afr lang & Educ & State & All & Full \\
\hline \multirow{2}{*}{$\begin{array}{l}\text { Non-Hispanic } \\
\text { generation } 3+\end{array}$} & $-0.204^{* * *}$ & $-0.206^{* * *}$ & $-0.206^{* * *}$ & $-0.206^{* * *}$ & $-0.224^{* * *}$ & $-0.224^{* * *}$ & $-0.199^{* * *}$ \\
\hline & {$[0.0032]$} & {$[0.0032]$} & {$[0.0032]$} & {$[0.0032]$} & {$[0.0033]$} & [0.0033] & [0.0031] \\
\hline \multirow[t]{2}{*}{ Hispanic generation 3+ } & $-0.161^{* * *}$ & $-0.155^{* * *}$ & $-0.155^{* * *}$ & $-0.155^{* * *}$ & $-0.16^{* * *}$ & $-0.16^{* * *}$ & $-0.127^{* * *}$ \\
\hline & {$[0.0240]$} & {$[0.0239]$} & {$[0.0239]$} & {$[0.0239]$} & [0.0239] & {$[0.0239]$} & {$[0.0211]$} \\
\hline \multirow[t]{2}{*}{ Caribbean-English 2} & $-0.0756^{* *}$ & $-0.0801^{* * *}$ & $-0.0801^{* * *}$ & $-0.0801^{* * *}$ & $-0.0863^{* * *}$ & $-0.0863^{* * *}$ & $-0.139^{* * *}$ \\
\hline & {$[0.0296]$} & {$[0.0293]$} & [0.0293] & {$[0.0293]$} & [0.0292] & {$[0.0292]$} & {$[0.0248]$} \\
\hline \multirow[t]{2}{*}{ Caribbean-Spanish 2} & $-0.115^{* * *}$ & $-0.109^{* * *}$ & $-0.109^{* * *}$ & $-0.109^{* * *}$ & $-0.118^{* * *}$ & $-0.118^{* * *}$ & $-0.109^{* * *}$ \\
\hline & {$[0.0412]$} & {$[0.0412]$} & {$[0.0412]$} & {$[0.0412]$} & {$[0.0411]$} & {$[0.0411]$} & {$[0.0375]$} \\
\hline \multirow[t]{2}{*}{ Haiti 2} & $-0.212^{* * *}$ & $-0.209^{* * *}$ & $-0.209^{* * *}$ & $-0.209^{* * *}$ & $-0.195^{* * *}$ & $-0.195^{* * *}$ & $-0.168^{* * *}$ \\
\hline & {$[0.0586]$} & {$[0.0585]$} & {$[0.0585]$} & {$[0.0585]$} & {$[0.0573]$} & [0.0573] & {$[0.0540]$} \\
\hline \multirow[t]{2}{*}{ African 2} & -0.0706 & -0.082 & & -0.0825 & $-0.113^{* *}$ & & \\
\hline & [0.0509] & {$[0.0505]$} & & {$[0.0505]$} & {$[0.0510]$} & & \\
\hline \multirow[t]{2}{*}{ African-English 2} & & & $-0.139 * *$ & & & $-0.169^{* * *}$ & $-0.185^{* * *}$ \\
\hline & & & [0.0619] & & & {$[0.0621]$} & {$[0.0520]$} \\
\hline \multirow[t]{2}{*}{ African-Non-English 2} & & & 0.0244 & & & -0.0117 & -0.0263 \\
\hline & & & [0.0859] & & & [0.0880] & {$[0.0690]$} \\
\hline \multirow[t]{2}{*}{ Other immigrants 2} & $-0.126^{* * *}$ & $-0.124^{* * *}$ & $-0.124^{* * *}$ & $-0.124^{* * *}$ & $-0.137^{* * *}$ & $-0.137^{* * *}$ & $-0.132^{* * *}$ \\
\hline & [0.0259] & {$[0.0258]$} & {$[0.0258]$} & {$[0.0258]$} & {$[0.0257]$} & {$[0.0257]$} & {$[0.0249]$} \\
\hline \multirow[t]{2}{*}{ Citizen } & $0.0519^{* * *}$ & $0.0528^{* * *}$ & $0.0526^{* * *}$ & $0.0509^{* * *}$ & $0.0531^{* * *}$ & $0.051^{* * *}$ & $0.0303^{* *}$ \\
\hline & {$[0.0150]$} & {$[0.0150]$} & {$[0.0150]$} & {$[0.0152]$} & {$[0.0150]$} & {$[0.0152]$} & {$[0.0148]$} \\
\hline \multirow[t]{2}{*}{ Caribbean-English } & $-0.0731^{* * *}$ & $-0.0727^{* * *}$ & $-0.0727^{* * *}$ & $-0.0746^{* * *}$ & $-0.0748^{* * *}$ & $-0.0775^{* * *}$ & $-0.0589^{* * *}$ \\
\hline & {$[0.0184]$} & {$[0.0184]$} & [0.0184] & {$[0.0204]$} & {$[0.0184]$} & {$[0.0204]$} & [0.0199] \\
\hline \multirow[t]{2}{*}{ Caribbean-Spanish } & $-0.178^{* * *}$ & $-0.176^{* * *}$ & $-0.176^{* * *}$ & $-0.177^{* * *}$ & $-0.187^{* * *}$ & $-0.189^{* * *}$ & $-0.154^{* * *}$ \\
\hline & {$[0.0245]$} & {$[0.0244]$} & {$[0.0244]$} & {$[0.0253]$} & {$[0.0244]$} & [0.0253] & {$[0.0246]$} \\
\hline \multirow[t]{2}{*}{ Haiti } & $-0.253^{* * *}$ & $-0.255^{* * *}$ & $-0.255^{* * *}$ & $-0.256^{* * *}$ & $-0.239^{* * *}$ & $-0.241^{* * *}$ & $-0.22^{* * *}$ \\
\hline & {$[0.0226]$} & {$[0.0225]$} & {$[0.0225]$} & {$[0.0235]$} & {$[0.0225]$} & {$[0.0235]$} & {$[0.0236]$} \\
\hline \multirow[t]{2}{*}{ African } & $-0.196^{* * *}$ & $-0.196^{* * *}$ & & $-0.199^{* * *}$ & $-0.216^{* * *}$ & & \\
\hline & {$[0.0186]$} & {$[0.0186]$} & & [0.0197] & {$[0.0186]$} & & \\
\hline \multirow[t]{2}{*}{ African-English } & & & $-0.166^{* * *}$ & & & $-0.188^{* * *}$ & $-0.168^{* * *}$ \\
\hline & & & {$[0.0223]$} & & & {$[0.0233]$} & {$[0.0230]$} \\
\hline \multirow[t]{2}{*}{ African-French } & & & $-0.315^{* * *}$ & & & $-0.331^{* * *}$ & $-0.28^{* * *}$ \\
\hline & & & {$[0.0746]$} & & & {$[0.0746]$} & {$[0.0733]$} \\
\hline \multirow[t]{2}{*}{ African-Other lang. } & & & $-0.223^{* * *}$ & & & $-0.246^{* * *}$ & $-0.22^{* * *}$ \\
\hline & & & {$[0.0235]$} & & & {$[0.0245]$} & {$[0.0238]$} \\
\hline \multirow[t]{2}{*}{ Other immigrants } & $-0.163^{* * *}$ & $-0.163^{* * *}$ & $-0.163^{* * *}$ & $-0.164^{* * *}$ & $-0.169^{* * *}$ & $-0.171^{* * *}$ & $-0.146^{* * *}$ \\
\hline & [0.0209] & {$[0.0208]$} & [0.0208] & {$[0.0219]$} & {$[0.0208]$} & {$[0.0219]$} & {$[0.0209]$} \\
\hline \multirow[t]{2}{*}{ Arrived pre-1965 } & $-0.158^{* * *}$ & $-0.185^{* * *}$ & $-0.185^{* * *}$ & $-0.184^{* * *}$ & $-0.183^{* * *}$ & $-0.181^{* * *}$ & $-0.172^{* * *}$ \\
\hline & {$[0.0261]$} & {$[0.0261]$} & {$[0.0261]$} & {$[0.0269]$} & {$[0.0261]$} & {$[0.0269]$} & {$[0.0259]$} \\
\hline \multirow[t]{2}{*}{ Arrived 1965-1974 } & $-0.198^{* * *}$ & $-0.223^{* * *}$ & $-0.223^{* * *}$ & $-0.222^{* * *}$ & $-0.227^{* * *}$ & $-0.226^{* * *}$ & $-0.215^{* * *}$ \\
\hline & {$[0.0250]$} & {$[0.0250]$} & {$[0.0250]$} & {$[0.0255]$} & {$[0.0250]$} & {$[0.0255]$} & {$[0.0247]$} \\
\hline \multirow[t]{2}{*}{ Arrived 1975-1981 } & $-0.19 * * *$ & $-0.209^{* * *}$ & $-0.209^{* * *}$ & $-0.208^{* * *}$ & $-0.21^{* * *}$ & $-0.209^{* * *}$ & $-0.186^{* * *}$ \\
\hline & {$[0.0239]$} & {$[0.0239]$} & {$[0.0239]$} & {$[0.0243]$} & [0.0239] & {$[0.0243]$} & [0.0239] \\
\hline
\end{tabular}


Table 11 Male hourly wage inequality: race, immigrant ethnicity, and age at arrival (selected coefficients), age $\geq 25$ (Continued)

\begin{tabular}{|c|c|c|c|c|c|c|c|}
\hline \multirow[t]{2}{*}{ Arrived 1982-1991 } & $-0.227^{* * *}$ & $-0.234^{* * *}$ & $-0.234^{* * *}$ & $-0.233^{* * *}$ & $-0.239 * * *$ & $-0.237^{* * *}$ & $-0.197^{* * *}$ \\
\hline & {$[0.0224]$} & {$[0.0224]$} & {$[0.0224]$} & {$[0.0229]$} & {$[0.0224]$} & {$[0.0230]$} & {$[0.0224]$} \\
\hline \multirow[t]{2}{*}{ Arrived 1992-2001 } & $-0.254^{* * *}$ & $-0.252^{* * *}$ & $-0.251^{* * *}$ & $-0.25^{* * *}$ & $-0.253^{* * *}$ & $-0.251^{* * *}$ & $-0.173^{* * *}$ \\
\hline & {$[0.0233]$} & {$[0.0232]$} & {$[0.0233]$} & {$[0.0237]$} & {$[0.0232]$} & {$[0.0237]$} & {$[0.0230]$} \\
\hline \multirow[t]{2}{*}{ Arrived 2002-2007 } & $-0.263^{* * *}$ & $-0.251^{* * *}$ & $-0.25^{* * *}$ & $-0.248^{* * *}$ & $-0.254^{* * *}$ & $-0.251^{* * *}$ & $-0.155^{* * *}$ \\
\hline & {$[0.0282]$} & [0.0282] & {$[0.0282]$} & {$[0.0287]$} & [0.0282] & {$[0.0287]$} & {$[0.0278]$} \\
\hline \multirow[t]{2}{*}{ Arrived 2008-2013 } & $-0.3^{* * *}$ & $-0.297^{* * *}$ & $-0.292^{* * *}$ & $-0.295^{* * *}$ & $-0.308^{* * *}$ & $-0.301^{* * *}$ & $-0.181^{* * *}$ \\
\hline & {$[0.0485]$} & {$[0.0485]$} & {$[0.0485]$} & {$[0.0487]$} & {$[0.0481]$} & {$[0.0484]$} & {$[0.0479]$} \\
\hline \multirow[t]{2}{*}{ Child $(\leq 12)$} & $0.137^{* * *}$ & $0.158^{* * *}$ & $0.158^{* * *}$ & $0.157^{* * *}$ & $0.154^{* * *}$ & $0.152^{* * *}$ & $0.148^{* * *}$ \\
\hline & {$[0.0239]$} & [0.0239] & {$[0.0239]$} & {$[0.0249]$} & {$[0.0238]$} & {$[0.0249]$} & {$[0.0237]$} \\
\hline \multirow[t]{2}{*}{ Adolescent (13-17) } & $0.0756^{* * *}$ & $0.0871^{* * *}$ & $0.0879^{* * *}$ & $0.0853^{* * *}$ & $0.0825^{* * *}$ & $0.0804^{* * *}$ & $0.0885^{* * *}$ \\
\hline & {$[0.0256]$} & {$[0.0256]$} & {$[0.0256]$} & {$[0.0272]$} & {$[0.0255]$} & {$[0.0272]$} & {$[0.0264]$} \\
\hline \multirow[t]{2}{*}{ Emerging adult (18-25) } & $0.0416^{*}$ & $0.0529^{* *}$ & $0.0525^{* *}$ & $0.0511^{* *}$ & $0.0494^{* *}$ & $0.0472^{* *}$ & 0.0324 \\
\hline & {$[0.0224]$} & [0.0224] & {$[0.0224]$} & {$[0.0225]$} & [0.0224] & {$[0.0225]$} & {$[0.0220]$} \\
\hline \multirow[t]{2}{*}{ Young adult (26-34) } & -0.0315 & -0.0367 & -0.036 & -0.0363 & $-0.0406^{*}$ & $-0.0395^{*}$ & $-0.107^{* * *}$ \\
\hline & {$[0.0233]$} & [0.0233] & {$[0.0233]$} & {$[0.0233]$} & {$[0.0233]$} & {$[0.0233]$} & {$[0.0230]$} \\
\hline \multirow[t]{2}{*}{ Advanced adult (35-44) } & $-0.0788^{* * *}$ & $-0.101^{* * *}$ & $-0.102^{* * *}$ & $-0.1^{* * *}$ & $-0.102^{* * *}$ & $-0.103^{* * *}$ & $-0.168^{* * *}$ \\
\hline & {$[0.0277]$} & {$[0.0278]$} & {$[0.0278]$} & {$[0.0278]$} & {$[0.0278]$} & {$[0.0278]$} & {$[0.0276]$} \\
\hline \multirow[t]{2}{*}{ Middle-age (45-54) } & $-0.114^{* * *}$ & $-0.128^{* * *}$ & $-0.129^{* * *}$ & $-0.128^{* * *}$ & $-0.131^{* * *}$ & $-0.132^{* * *}$ & $-0.196^{* * *}$ \\
\hline & {$[0.0378]$} & {$[0.0376]$} & {$[0.0376]$} & {$[0.0376]$} & {$[0.0375]$} & {$[0.0376]$} & {$[0.0374]$} \\
\hline \multirow[t]{2}{*}{ Senior (55-64) } & -0.0448 & -0.00553 & -0.00138 & -0.00549 & 0.00208 & 0.00648 & -0.124 \\
\hline & {$[0.1080]$} & [0.1066] & {$[0.1066]$} & {$[0.1066]$} & {$[0.1069]$} & {$[0.1070]$} & [0.1079] \\
\hline$R$-sq & 0.2319 & 0.2339 & 0.2339 & 0.2339 & 0.2395 & 0.2395 & 0.4256 \\
\hline N & 590,439 & 590,439 & 590,439 & 590,439 & 590,439 & 590,439 & 703,797 \\
\hline
\end{tabular}

Source: author's calculations. March CPS, 1994-2013. Additional control variables also include citizenship status, educational status (11 years or less, 13-15 years, 16 years, 17 years or more), experience (binary variables for each 5-year interval from 6 to 35 years, plus a binary variable for more than 36 years of experience), age, age ${ }^{2}$, age ${ }^{3}$, marital status, region, size of city, health status, year fixed effects, state fixed effects, and state*trend interaction effects. Robust standard errors are reported in parentheses

${ }^{*} p<0.10 ;{ }^{* *} p<0.05 ;{ }^{* * *} p<0.01$

\section{Competing interests}

The IZA Journal of Migration is committed to the IZA Guiding Principles of Research Integrity. The author declares that he has observed these principles.

\section{Acknowledgements}

I would like to thank the editor and the anonymous referee for the useful comments.

Responsible editor: Denis Fougère

Received: 8 December 2015 Accepted: 29 May 2016

Published online: 12 September 2016

\section{References}

Borjas GJ. The slowdown in the economic assimilation of immigrants: aging and cohort effects revisited again. J Hum Cap. 2015;9(4):483-517.

Borjas GJ. Assimilation and changes in cohort quality revisited: what happened to immigrant earnings in the 1980s. J Labor Econ. 1995;13(2):201-45.

Borjas GJ. Assimilation, changes in cohort quality, and the earnings of immigrants. J Labor Econ. 1985;3(4):463-89.

Butcher KE. Black immigrants in the United States: a comparison with native blacks and other immigrants. Ind Labor Relat Rev. 1994:47(2):165-284.

Chiswick BR. The effect of Americanization on the earnings of foreign-born men. J Polit Econ. 1978;86(5):897-921.

Darity Jr W. What's left of the economic theory of discrimination? In: Shulman S, Darity Jr W, editors. The question of discrimination. Middletown: Wesleyan University Press; 1989. p. 335-74. 
Dodoo FN-A, Takyi BK. Africans in the diaspora: black-white earnings differences among America's Africans. Ethnic Racial Stud. 2002;25(6):913-41.

Dodoo FN-A. Assimilation differences among Africans in America. Soc Forces. 1997;76(2):527-46.

Foner N. West Indians in New York City and London: a comparative analysis. Int Migr Rev. 1979;13(2):284-97. Special Issue: International Migration in Latin America, Summer.

Hamilton TG. Selection, language heritage, and the earnings trajectories of black immigrants in the United States. Demography. 2014;51(3):975-1002.

Hamilton TG. Arrival cohort, assimilation, and the earnings of Caribbean women. Rev Black Pol Econ. 2012;39(4):445-60

Ifatunji M. Socioeconomic disparities between African Americans and Caribbeans in the US: re-examining the role of immigrant selectivity, University of North Carolina, working paper. 2013a.

Ifatunji M. The Afro Caribbean 'model minority' hypothesis: the role of cultural attributes in socioeconomic disparities between African Americans and Afro Caribbeans, University of North Carolina, working paper. 2013b.

Kalmijn M. The socioeconomic assimilation of Caribbean American blacks. Soc Forces. 1996;74(3):911-30.

Kent MM. Immigration and America's Black population. Popul Bull. 2007;62(4):3-16.

Model S. West Indian immigrants: a black success story? New York: Russell Sage Foundation; 2008.

Model S. Caribbean immigrants: a black success story? Int Migr Rev. 1991;25(2):248-76.

Ottaviano G, Peri G. Rethinking the effects of immigration on wages. J Eur Econ Assoc. 2012;10(1):152-97.

Pierre J. Black immigrants in the United States and the "cultural narratives" of ethnicity. Identities Glob Stud Cult Power. 2004;11:141-70.

Sakamoto A, Woo H, Kim CH. Does an immigrant background ameliorate racial disadvantage? The socioeconomic attainments of second-generation African Americans. Sociol Forum. 2010;25(1):123-46.

Thomas-Hope E. International migration based on analysis of the 2000 Round Census Data of eighteen Caribbean countries. In: Regional special topic monograph. Georgetown, Guyana: The CARICOM Secretariat; 2009.

The World Factbook 2013-14. Washington, DC: Central Intelligence Agency, 2013. https://www.cia.gov/library/ publications/the-world-factbook/index.html

Submit your manuscript to a SpringerOpen ${ }^{\circ}$ journal and benefit from:

- Convenient online submission

- Rigorous peer review

- Immediate publication on acceptance

- Open access: articles freely available online

- High visibility within the field

- Retaining the copyright to your article

Submit your next manuscript at $>$ springeropen.com 